\title{
Is There a New Extraterritoriality in Intellectual Property?
}

\author{
Timothy R. Holbrook ${ }^{*}$
}

\section{TABLE OF CONTENTS}

Introduction 458

I. The Landscape: Extraterritoriality in Intellectual Property Before the

Supreme Court's Recent Interventions

A. Trademark's Historical Extraterritorial Reach .......................461

1. Is Extraterritoriality Jurisdictional or Part of the Merits?..463

2. The Extraterritorial Reach of Trademark Law

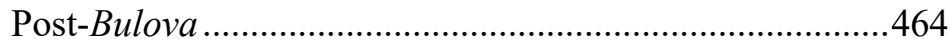

B. Copyright Law's Stronger Territorial Limits ...........................466

1. Is Extraterritoriality Jurisdictional or Part of the Merits?...466

2. Copyright Infringement Determinations 467

3. Copyright Infringement Damages and the Predicate Act Doctrine

C. Patent Law

1. Is Extraterritoriality Jurisdictional or Part of the Merits?...473

2. Patent Infringement Determinations ....................................474

3. Patent Infringement Damages...........................................477

II. The Transformation of Extraterritoriality by the Supreme Court

Tetralogy

A. The Supreme Court Gives the Presumption More Teeth in Morrison v. National Australia Bank

B. Expanding the Application of the Presumption in Kiobel v. Royal Dutch Petroleum Co.

C. Formalizing a Two-Step Methodology in RJR Nabisco, Inc. v.

European Community

* Vice Provost for Faculty Affairs, Emory University; Asa Griggs Candler Professor of Law, Emory University School of Law. Thanks to Bill Dodge for his thoughtful comments and Sam Leff for her outstanding legal research and assistance.

(C) 2021 Holbrook. This is an open access article distributed under the terms of the Creative Commons Attribution License, which permits unrestricted use, distribution, and reproduction, provided the original author and source are credited. 
D. The Supreme Court Applies Step Two in WesternGeco LLC v.

ION Geophysical Corp.

III. Is There a New Extraterritoriality in Intellectual Property? ...............484

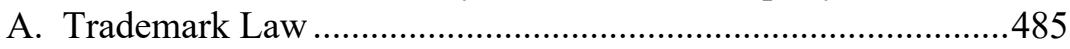

1. Extraterritoriality Is Not a Jurisdictional Question..............486

2. The Mixed, Somewhat Odd Application of RJR Nabisco To

Trademark Liability Determinations..................................487

B. Copyright Law......................................................................491

1. Morrison Is Leading Towards Extraterritoriality in Copyright

Not Being Jurisdictional ..................................................491

2. Courts' Engagement with the Supreme Court's Recent Case

Law Is Mixed

3. The Predicate Act Doctrine Survives the Supreme Court's

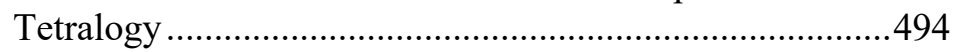

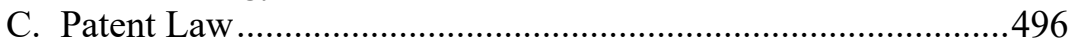

IV. Intellectual Property Extraterritoriality Remains Inconsistent . . But It

Shouldn't.

A. Assessing the Overall Impact on Trademark, Copyright, and Patent 505

B. Potential Benefits if Courts Align with the RJR Nabisco

Framework. .506

C. As in Trademark, Is There a Role for Comity in Patent and Copyright? .507

\section{INTRODUCTION}

Intellectual property ("IP") rights are creatures of national law. Individual countries define and enforce them. These exclusive rights are also territorially limited and thus generally do not extend outside of the country that has provided the rights. Instead, they are limited to activities within the country.

At least, that is how the situation would appear by reading various national statutes and international treaties. The reality is far more complex. In the global marketplace, such territorial rights do not map onto the commercial realities of many companies. Their products, services, and activities routinely cross borders, and some networked systems straddle territorial lines. Just think of the internet-its virtual tentacles extend across borders and around the world. Given the global marketplace and the intangible-yet-territorial nature of intellectual property rights, IP sits squarely in the middle of concerns about extraterritoriality. The patchwork of national rights can be ill-fitting to protect products that travel the world and systems that reach into multiple countries. Right holders are faced with knitting together a patchwork of IP rights 
across various countries. Ensuring a complete tapestry in such a framework can be difficult. It is unsurprising, then, that IP owners attempt to leverage the rights in one country into the markets of another country, thereby applying those exclusive rights extraterritorially.

Within the United States, applying U.S. law to activities in other countries is disfavored by the courts. This principle transcends intellectual property law and applies generally to all laws. The U.S. Supreme Court has long articulated a presumption against the extraterritorial application of U.S. law. ${ }^{1}$ This is not to say that Congress does not have the power to make U.S. law apply outside of the U.S. territorial boundaries. It is well settled that Congress has such power, particularly as it relates to U.S. citizens. ${ }^{2}$ Nevertheless, extending U.S. law to foreign acts creates a host of complications, particularly as an affront to the sovereignty of the country within which the relevant activity is taking place. Given the political dimensions of extraterritoriality, courts tread lightly when deciding to apply U.S. law to foreign acts, generally requiring a clear expression of Congressional intent.

Even though the presumption against extraterritoriality is long-standing in American jurisprudence, the courts have applied it inconsistently. In recent years, the Supreme Court has sought to reinvigorate the presumption and harmonize its use across all areas of law. ${ }^{3}$ Patent law has been a key driver of the evolution of this presumption in the Court. The use of patent law as a lever for this development is somewhat surprising because patent law is generally viewed as the most territorial of the three main federal forms of IP protection (the other two being copyright and trademark). ${ }^{4}$ Nevertheless, patent cases have been central to the work the Court has done with respect to the presumption. The full impact of the Supreme Court's cases in the patent context is still unfolding at the U.S. Court of Appeals for the Federal Circuit, the court that hears all appeals arising under the patent laws of the United States. $^{5}$

But what impact has this line of cases had on the other areas of intellectual property? Given the Court's efforts to create a trans-substantive presumption, has a more uniform approach to extraterritoriality emerged across these three IP regimes, or does the law remain fractured? And, if the law is fractured, could that nevertheless be the correct answer given the unique policies underlying each of these areas of IP?

1. Foley Bros. v. Filardo, 336 U.S. 281, 285 (1949); Blackmer v. United States, 284 U.S. 421, 437 (1932); Am. Banana Co. v. United Fruit Co., 213 U.S. 347, 357 (1909). For a history of the presumption, see William S. Dodge, The New Presumption Against Extraterritoriality, 133 HARV. L. ReV. 1582, 15891603 (2020). See also John H. Knox, A Presumption Against Extrajurisdictionality, 104 AM. J. INT'L L. 351, 361-78 (2010).

2. Steele v. Bulova Watch Co., 344 U.S. 280, 282 (1952) ("Congress in prescribing standards of conduct for American citizens may project the impact of its laws beyond the territorial boundaries of the United States.").

3. See Dodge, supra note 1, at $1585-86$.

4. Donald S. Chisum, Normative and Empirical Territoriality in Intellectual Property: Lessons from Patent Law, 37 VA. J. INT'L L. 603, 605 (1997) ("Of the three principal forms of intellectual property, patent rights are most explicitly territorial.").

5. 28 U.S.C. $\S 1295(\mathrm{a})(1)$. 
This Article is the first to comprehensively interrogate the impact of the Supreme Court's recent interventions in extraterritoriality as it relates to the three historical forms of federal intellectual property: patent, copyright, and trademark. ${ }^{6}$ In this manner, it fills an important gap in the literature because most assessments of the presumption focus only on one area of law. Moreover, this Article offers a novel comparative assessment of the evolution of the presumption across the patent, copyright, and trademark regimes, offering both a descriptive account of the state and evolution of the law, as well as a normative assessment of whether the current state of the law best effectuates the policies that justify these forms of protection.

In reviewing the application of the Supreme Court's recent jurisprudence in these three areas of intellectual property, the Article concludes that the Supreme Court's effort to standardize the law of extraterritoriality has failed. Lower courts' engagement with the presumption has been, at best, inconsistent. There are times where the courts simply ignore the Court's recent cases, relying on previous cases and doctrine without pausing to reconsider whether those doctrines survive the Supreme Court's latest changes to the law. The Article also concludes that this inconsistency cannot be justified based on the differing policies surrounding copyright, trademarks, and patents.

This Article proceeds as follows. Part I discusses the state of the law of extraterritoriality in copyright, trademark, and patent, as it stood before the Supreme Court's recent intervention. This review demonstrates that all three disciplines were treating extraterritoriality very differently, and none were paying much attention to the presumption against extraterritoriality. Part II reviews a tetralogy of recent Supreme Court cases, describing the Court's attempt to formalize its approach to extraterritoriality across all fields of law. Part III analyzes the state of IP law in the aftermath of this tetralogy of extraterritoriality cases. It concludes that there has been some impact on patent law, but virtually none on copyright or trademark. The Article assesses whether there is a new extraterritoriality for intellectual property and concludes that there is not: The Supreme Court's efforts, at least in IP, have not led to greater coherence. While there may be reasons for the lower courts' failure to follow the framework, it does represent a missed opportunity for cross-fertilization, at least among intellectual property regimes, if not across all fields of law. It also offers a call for the consideration of comity - looking to foreign law and potential conflicts - in deciding whether to apply U.S. law extraterritorially.

6. Trade secrecy has not been immune to extraterritorial considerations under the Defend Trade Secrets Act (DTSA). See, e.g., Motorola Sols., Inc. v. Hytera Commc'ns Corp., 436 F. Supp. 3d 1150, 1157 (N.D. Ill. 2020). The DTSA was passed after the Supreme Court's intervention, so it would be impossible to assess the change in the law. Thus, this Article does not include trade secret misappropriation. The Motorola court held that the DTSA did apply extraterritorially. Id. at 1163. For a discussion of extraterritoriality in trade secrecy law generally, see Elizabeth A. Rowe \& Giulia C. Farrior, Revisiting Trade Secret Extraterritoriality, 25 B.U. J. SCI. \& TECH. L. 431 (2019); Elizabeth A. Rowe \& Daniel M. Mahfood, Trade Secrets, Trade, and Extraterritoriality, 66 ALA. L. REV. 63 (2014). 


\section{THE LANDSCAPE: EXTRATERRITORIALITY IN INTELLECTUAL PROPERTY BEFORE THE SUPREME COURT'S RECENT INTERVENTIONS}

Issues of extraterritoriality in intellectual property are not new. Each form of intellectual property has wrestled with how to deal with extraterritorial or transborder infringement issues. Nevertheless, these issues have come to the fore in the modern era with the global trading system and technologies such as software, digital products, and the internet, all of which have reduced the power of national borders as barriers to trade. This Part reviews the law of extraterritoriality that developed, before the Supreme Court's recent interventions, in each of the three federal forms of IP protection: trademark, copyright, and patent.

\section{A. Trademark's Historical EXtraterritorial Reach}

Trademark is somewhat unique as a federal form of intellectual property. Congressional authority to enact the Lanham Act, the federal trademark statute, rests in the Commerce Clause of the U.S. Constitution, ${ }^{7}$ rather than its Intellectual Property Clause, which empowers Congress to create the copyright and patent systems. ${ }^{8}$ Trademark is concerned with commerce, which includes regulation of "commerce with foreign nations." 9 As such, the nature of the rights and the policies implicated by trademark can differ from those of patent and copyright. Whereas patent and copyright are justified in the United States primarily on utilitarian grounds, providing exclusive rights to prevent free riding on another's invention or writing, ${ }^{10}$ trademark law balances consumer protection, producers' goodwill, and market competition. ${ }^{11}$ Given these foci, and Congress's express power to regulate commerce with foreign nations, trademark law is positioned for increased extraterritorial consideration.

Indeed, trademarks have long had extraterritorial reach under Supreme Court precedent. As Graeme W. Austin noted, "[o]f the major intellectual property rights, trademark rights have long been the most susceptible to extraterritorial application."12 The reputation of a mark could easily cross borders, allowing American consumers to be familiar with a foreign trademark. In contrast to patent and copyright, the extraterritorial reach of the Lanham Act has never been controlled

7. U.S. ConST. art. I, § 8, cl. 3. See United We Stand Am., Inc. v. United We Stand, Am. N.Y., Inc., 128 F.3d 86, 92 (2d Cir. 1997) ("The history and text of the Lanham Act show that 'use in commerce' reflects Congress's intent to legislate to the limits of its authority under the Commerce Clause, rather than to limit the Lanham Act to profit-seeking uses of a trademark.").

8. U.S. ConST. art. I, § 8, cl. 8. See The Trade-Mark Cases, 100 U.S. 82, 93 (1879) (holding an early federal trademark statute not authorized by the Patent and Copyright Clause).

9. U.S. CONST. art. I, \& 8, cl. 3.

10. See Roger D. Blair \& Thomas F. Cotter, The Elusive Logic of Standing Doctrine in Intellectual Property Law, 74 TUL. L. REV. 1323, 1380 (2000)

11. See Clarisa Long, Dilution, 106 Colum. L. Rev. 1029, 1033-35 (2006).

12. Graeme W. Austin, Importing Kazaa-Exporting Grokster, 22 SANTA ClaRA COMPUT. \& HigH TECH. L.J. 577, 602 (2006). 
by a locus analysis in which a court identifies the location of the act of infringement. Instead, the focus has been on the effect infringement may have on commerce. ${ }^{13}$

The seminal Supreme Court decision as to the extraterritorial reach of the Lanham Act is Steele v. Bulova Watch Co. ${ }^{14}$ The case, even after nearly seventy years, remains the key precedent in assessing extraterritoriality in the trademark area. The Supreme Court has not overruled Bulova, even though its recent engagement with the presumption against extraterritoriality is arguably in tension with it.

In Bulova, the trademark owner asserted infringement against a U.S. citizen who was selling counterfeit watches in Mexico. ${ }^{15}$ Although at one point the accused infringer had a trademark registration in Mexico for the mark "Bulova," the Mexican government revoked it prior to the Supreme Court's decision. ${ }^{16}$ A number of the counterfeit watches made their way back into the United States, particularly along the Texas-Mexico border. ${ }^{17}$ However, most of the alleged infringement took place in Mexico and not in the United States.

The Supreme Court concluded that a U.S. court could hear the case under U.S. trademark law. ${ }^{18}$ The Court held that, under these facts, jurisdiction was appropriate, permitting the extraterritorial application of federal trademark law in the infringement context. ${ }^{19}$ The Court noted that the Lanham Act "confers broad jurisdictional powers upon the courts of the United States," 20 and concluded that Congress's definition of "commerce" in the Act encompasses "all commerce which may lawfully be regulated by Congress," including extraterritorial conduct. ${ }^{21}$ In holding that U.S. law applied, the Court recognized that Congress has the power to regulate U.S. citizens wherever they may be in the world. ${ }^{22}$ The Court also concluded that the infringer's "operations and their effects were not confined within the territorial limits of a foreign nation", ${ }^{23}$ instead, there were effects within the United States. ${ }^{24}$ Finally, the Court found no

13. Wells Fargo \& Co. v. Wells Fargo Exp. Co., 556 F.2d 406, 428 (9th Cir. 1977) ("[T]he extraterritorial coverage of the Lanham Act should be gauged not so much by the locus of the activity sought to be reached ... as by the nature of its effect on that commerce which Congress may regulate.").

14. 344 U.S. 280 (1952).

15. Id. at 281 .

16. Id. at 285 .

17. $I d$.

18. Id. at 285 ("On the facts in the record we agree with the Court of Appeals that petitioner's activities, when viewed as a whole, fall within the jurisdictional scope of the Lanham Act."). This language led to the uncertainty, discussed infra notes 32-39 and accompanying text, as to whether extraterritoriality is jurisdictional in nature.

19. Id. at 291-92.

20. Id. at 283 .

21. Id. at 287 ("We do not deem material that petitioner affixed the mark 'Bulova' in Mexico City rather than here, or that his purchases in the United States when viewed in isolation do not violate any of our laws. They were essential steps in the course of business consummated abroad; acts in themselves legal lose that character when they become part of an unlawful scheme.") (citations omitted).

22. Id. at 283 .

23. Id. at 286 .

24. Id. 
conflict with foreign law because the Mexican courts had rescinded the accused infringer's Mexican trademark registration. ${ }^{25}$

In so holding, the Court did not reference the presumption and seemingly did not apply it. Indeed, the Court decided Bulova during a period when it generally was not applying the presumption. ${ }^{26}$ The dissent called out this oversight, articulating that federal law generally only applies domestically absent a contrary Congressional intent. ${ }^{27}$ The dissent did not find the requisite intent to justify extending the Lanham Act extraterritorially. ${ }^{28}$ Nevertheless, the majority's holding and reasoning continue to be influential today.

\section{Is Extraterritoriality Jurisdictional or Part of the Merits?}

In the years following Bulova, a threshold issue that the courts had to confront was the nature of the question itself: Is extraterritoriality a jurisdictional question or a question of the sufficiency of the merits of the case?

This distinction may seem minor, but it is important. Jurisdictional questions implicate the power of the court to hear the case at all, whereas questions of substance go to whether the plaintiffs have pleaded or proven their cases adequately. The distinction is also important procedurally: Questions of jurisdiction can be raised at any point during the proceedings, whereas questions about pleadings, such as motions to dismiss for failure to state a claim, cannot be raised once the trial has started. ${ }^{29}$

The Court characterized the issue in Bulova as jurisdictional. ${ }^{30}$ In its seminal case E.E.O.C. v. Arabian American Oil Co. (ARAMCO), the Supreme Court again stated that extraterritoriality is jurisdictional in nature. ${ }^{31}$

Consistent with this holding, many courts of appeals considered the issue to be jurisdictional in nature or, at least, they used such language. The First, Second, and Ninth Circuits, for example, treated the issue as one of subject matter jurisdiction. ${ }^{32}$

25. Id. at 289 ("Mexico's courts have nullified the Mexican registration of 'Bulova'; there is thus no conflict which might afford petitioner a pretext that such relief would impugn foreign law.").

26. Dodge, supra note 1, at 1595-98.

27. Bulova, 344 U.S.at 290 (Reed, J., dissenting).

28. Id. at 291-92.

29. Arbaugh v. Y\&H Corp., 546 U.S. 500, 506 (2006) ("The objection that a federal court lacks subject-matter jurisdiction, see Fed. Rule Civ. Proc. 12(b)(1), may be raised by a party, or by a court on its own initiative, at any stage in the litigation, even after trial and the entry of judgment. . . By contrast, the objection that a complaint 'fails to state a claim upon which relief can be granted,' Rule 12(b)(6), may not be asserted post trial.").

30. Bulova, 344 U.S. at 281 ("The issue is whether a United States District Court has jurisdiction [over the case] ....").

31. E.E.O.C. v. Arabian Am. Oil Co., 499 U.S. 244, 249 (1991) ("Petitioners argue that by its plain language, Title VII's 'broad jurisdictional language' reveals Congress' intent to extend the statute's protections to employment discrimination anywhere in the world by a United States employer who affects trade 'between a State and any place outside thereof."').

32. See, e.g., McBee v. Delica Co., 417 F.3d 107, 120 (1st Cir. 2005) ("Absent a showing of such a substantial effect, at least as to foreign defendants, the court lacks jurisdiction over the Lanham Act claim."); Ocean Garden, Inc. v. Marktrade Co., 953 F.2d 500, 503 (9th Cir. 1991); Vanity Fair Mills, Inc. v. T. Eaton Co., 234 F.2d 633, 637 (2d Cir. 1956) ("On an appeal from a judgment granting a motion to 
The Supreme Court, however, disrupted such certainty, though in a different context. The Court recognized that the line between jurisdictional limits and substantive requirements of claims generally needed to be clarified. ${ }^{33}$ In Arbaugh $v$. $Y \& H$ Corp. , the Court attempted to articulate a bright-line rule, although the case did not involve the question of extraterritoriality. ${ }^{34}$ Instead, the question was whether Title VII's application to companies with fifteen or more employees was jurisdictional. ${ }^{35}$ The Court articulated the following rule:

If the Legislature clearly states that a threshold limitation on a statute's scope shall count as jurisdictional, then courts and litigants will be duly instructed and will not be left to wrestle with the issue. But when Congress does not rank a statutory limitation on coverage as jurisdictional, courts should treat the restriction as nonjurisdictional in character. $^{36}$

Although extraterritoriality was not at issue in Arbaugh, the Court did discuss $A R A M C O$, walking back its jurisdictional language. The Court acknowledged that the district court had placed the judgment "under a lack of subject-matter jurisdiction label," but that the Court had merely "copied the petitioners' characterizations of the terms. .."37 The Court reasoned that the decision in ARMACO "did not turn on" the jurisdictional characterization of the case and that "the parties did not cross swords over it."38 The Court essentially disclaimed that the issue was present in ARAMCO, and certainly was not decided, because the Court "was not prompted . . . to home in on whether the dismissal had been properly based on the absence of subject-matter jurisdiction rather than on the plaintiff's failure to state a claim."39

The Court, however, did not offer any clue as to its view of exterritoriality, nor did the Court address its language in Bulova. Arguably, Bulova suffers the same flaws as $A R A M C O$ in its use of jurisdictional language. Additionally, the various circuit courts approaching the question as jurisdictional did not have occasion to address squarely the nature of the question. Thus, the Court's move in Arbaugh, by interpreting $A R A M C O$, opened the door to reconsidering the nature of the extraterritoriality question in trademark law, as well as in other areas of intellectual property law.

\section{The Extraterritorial Reach of Trademark Law Post-Bulova}

Although Bulova approved of the extraterritorial application of federal trademark law, it did not articulate a clear rule for making that assessment. The courts have diverged in how they have applied Bulova's elaboration of the standard of liability

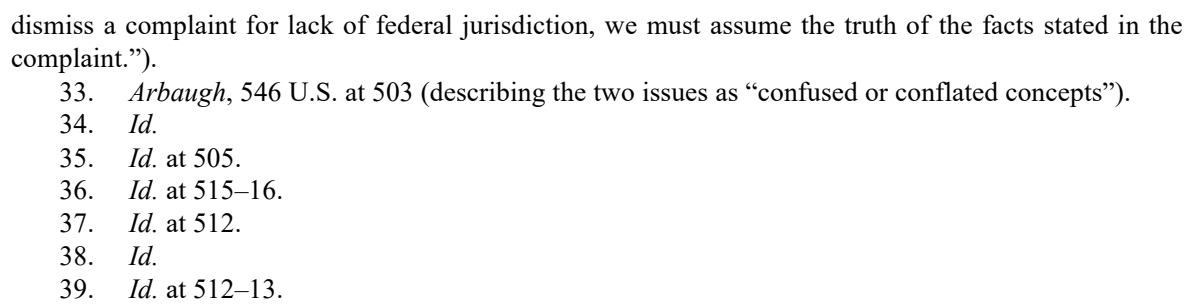


for trademark infringement. The appellate courts have distilled Bulova into three factors: (1) whether there is a substantial effect on U.S. commerce; (2) what the citizenship of the accused infringer is; and (3) whether exercising jurisdiction would create a conflict with foreign law. ${ }^{40}$

Aside from these factors, however, the regional circuit courts' applications of Bulova have varied widely. The Ninth Circuit embraced a sweeping "effects" test, akin to the approach it uses in antitrust law. ${ }^{41}$ In contrast, the Second Circuit embraced a more formalistic approach to these factors, seemingly deeming them necessary conditions and not merely factors to be balanced. ${ }^{42}$ The First Circuit offered a third approach, creating tiers in its application of the Bulova factors. ${ }^{43}$ That court reasoned that there is always jurisdiction if the accused infringer is a U.S. citizen, regardless of any effect on commerce, because Congress can always regulate the behavior of U.S. citizens anywhere in the world. ${ }^{44}$ In contrast, if the infringer is a noncitizen, then the infringement must have a substantial effect on U.S. commerce in order to find jurisdiction. ${ }^{45}$ Concerns with conflicts and comity, then, are assessed as jurisprudential considerations. ${ }^{46}$

What is interesting about all of this activity is the failure of courts to engage formally with the presumption against extraterritoriality. ${ }^{47}$ Although the Supreme Court in Bulova did not use the word "presumption" and seemingly failed to apply it ${ }^{48}$ the Court did recognize that "the legislation of Congress will not extend beyond the boundaries of the United States unless a contrary legislative intent appears." 49 But the courts have not subsequently discussed the presumption, perhaps viewing Bulova as having decided the issue, leaving no need to engage with it. By making clear that the Lanham Act has such reach, the Court may have immunized trademark law from a rich judicial engagement with the presumption. Indeed, the Supreme Court's recent articulations of the presumption seem, at best, in tension with Bulova, if not inconsistent with it.

40. E.g., Vanity Fair Mills, Inc. v. T. Eaton Co., 234 F.2d 633, 642 (2d Cir. 1956). See generally Graeme B. Dinwoodie, Developing a Private International Intellectual Property Law: The Demise of Territoriality?, 51 WM. \& MARY L. REV. 711, 780-82 (2009) (discussing various formulations of trademark tests); Timothy R. Holbrook, Extraterritoriality in U.S. Patent Law, 49 WM. \& MARY L. REV. 2119,2157 n.149 (2008) (discussing variations in trademark cases). Notwithstanding this variation, all of these approaches take into account citizenship and conflicts to some extent.

41. Wells Fargo \& Co. v. Wells Fargo Express Co., 556 F.2d 406, 427-29 (9th Cir. 1977).

42. Vanity Fair Mills, 234 F.2d at 643 (noting "the absence of one of the above factors might well be determinative and that the absence of both is certainly fatal").

43. McBee v. Delica Co., 417 F.3d 107, 118 (1st Cir. 2005)

44. Id. at 118 .

45. Id. at 120 .

46. Id. at 121 .

47. Curtis A. Bradley, Territorial Intellectual Property Rights in an Age of Globalism, 37 VA. J. INT'L L. 505, 533 (1997).

48. See supra notes $26-28$ and accompanying text.

49. Steele v. Bulova Watch Co., 344 U.S. 280, 285 (1952). 


\section{B. Copyright LaW's Stronger Territorial Limits}

While the courts have diverged on how to assess the Lanham Act's extraterritorial scope, Bulova at least greenlighted such use. The situation is quite different in the copyright context. Assessing the state of extraterritoriality in copyright can be a challenging endeavor. The courts of appeals have not been consistent in their approach, and indeed have frequently disagreed on the proper scope of extraterritorial protection permitted under the Copyright Act. Courts have made clear that these rights are territorial in nature, and copyright law has no extraterritorial application. ${ }^{50}$ Beyond that statement, however, the copyright law's extraterritorial scope is complicated. $^{51}$

\section{Is Extraterritoriality Jurisdictional or Part of the Merits?}

Similar to the situation in trademark law, the courts were split over whether extraterritoriality was jurisdictional or related to the substance of the cause of action under the Copyright Act. ${ }^{52}$

Prior to Arbaugh, the courts were in disarray on this issue. ${ }^{53}$ The Ninth Circuit itself was internally inconsistent, with its only clear holding being that the question

50. See, e.g., Litecubes, LLC v. N. Light Prod., Inc., 523 F.3d 1353, 1366 (Fed. Cir. 2008); Liberty Toy Co. v. Fred Silber Co., 149 F.3d 1183 (6th Cir. 1998) ("[I]t is a long-standing principle that United States copyright laws do not have extraterritorial operation."); Capitol Recs. v. Mercury Recs. Corp., 221 F.2d 657, 662 (2d Cir. 1955) ("Then too the rule that we are adopting is in harmony with the settled law that a copyright has no extra-territorial effect. ...").

51. The Supreme Court recently addressed one aspect of territoriality in the copyright context, the first sale doctrine, also known as exhaustion, holding that the first sale of a copyrighted item anywhere in the world exhausts the U.S. copyright over that item. Kirtsaeng v. John Wiley \& Sons, Inc., 568 U.S. 519, 530 (2013). The Supreme Court made no reference to the presumption in Kirtsaeng. See Dodge, supra note 1 , at 1607 . While implicating territoriality, one could argue that exhaustion does not create the same concerns of extraterritoriality because the application of U.S. law over foreign activity in this context creates only domestic consequences: the inability to enforce U.S. rights within the United States. See Timothy R. Holbrook, What Counts as Extraterritorial in Patent Law?, 25 B.U. J. SCI. \& TECH. L. 291, 296 (2019) [hereinafter Holbrook, What Counts?]. Nonetheless, one could see exhaustion as implicating extraterritoriality because actors may modify their behaviors in foreign countries, creating an indirect regulation of conduct in those countries. See id. at 324-25; see also Dodge, supra note 1, at 1607 (reconciling Kirtsaeng with Morrison). For the comparable circumstances in the patent context, see infra note 94 .

52. Shropshire v. Canning, 809 F. Supp. 2d 1139, 1143 (N.D. Cal. 2011) ("There is currently no clear consensus among the courts regarding whether the issue of the extraterritorial reach of the Copyright Act should be treated as a matter of subject matter jurisdiction, or should instead be treated as an element of a claim.").

53. Arbaugh v. Y\&H Corp., 546 U.S. 500 (2006). 
was jurisdictional. ${ }^{54}$ The Eleventh Circuit also viewed extraterritoriality as jurisdictional, ${ }^{55}$ as did the Southern District of New York. ${ }^{56}$

After Arbaugh, courts began to more seriously wrestle with this question and appeared to move away from a jurisdictional approach and towards viewing the issue as part of the substantive requirements of the claim. Relying on Arbaugh, the Federal Circuit concluded that extraterritoriality under the Copyright Act was an element of the claim and not jurisdictional because " $[\mathrm{t}]$ here is no indication that Congress intended the extraterritorial limitations on the scope of the Copyright Act to limit the subject matter jurisdiction of the federal courts." ${ }^{.57}$ A number of district courts have found the Federal Circuit's reasoning persuasive. ${ }^{58}$ Not all courts agreed, however. Prior to the Supreme Court's recent interventions on extraterritoriality, some courts continued to treat the issue as one of jurisdiction. ${ }^{59}$

\section{Copyright Infringement Determinations}

Putting the jurisdictional issues aside, there has been considerable debate within the copyright community about the extraterritorial reach of U.S. copyright protection. In the modern age of digital products and illegal downloading, this debate is perhaps expected. But this issue precedes those technological developments.

The exclusive rights afforded under copyright law are delineated in 17 U.S.C. $\S 106$, and they include the rights to make copies, to prepare derivative works, to distribute copies, to perform the work, and to display the work, as well as to authorize any of these acts. ${ }^{60}$ Interestingly, the statute does not specifically limit the scope of

54. Compare Peter Starr Prod. Co. v. Twin Continental Films, 783 F.2d 1440, 1442 (9th Cir.1986) (jurisdictional), with Subafilms, Ltd. v. MGM-Pathe Commc'ns Co., 24 F.3d 1088, 1091 n.5, 1095 (9th Cir. 1994) (en banc) (declining to answer whether "the Peter Starr court erred in framing the subject matter jurisdiction inquiry as coextensive with the question of whether the allegations in the complaint stated a good cause of action”). See generally Shropshire v. Canning, 809 F. Supp. 2d 1139, 1144 (N.D. Cal. 2011) (discussing the Ninth Circuit's inconsistency and broader circuit split).

55. Palmer v. Braun, 376 F.3d 1254, 1258 (11th Cir. 2004).

56. Well-Made Toy Mfg. Corp. v. Lotus Onda Indus. Co., No. 02 CIV. 1151 (CBM), 2003 WL 42001, at *5 (S.D.N.Y. Jan. 6, 2003).

57. Litecubes, LLC v. N. Light Prod., Inc., 523 F.3d 1353, 1368 (Fed. Cir. 2008). The Federal Circuit's reasoning was anomalous because it applied its own law to a copyright issue. For non-patent issues, the Federal Circuit generally applies the law of the regional circuit from which the case arose. Midwest Indus., Inc. v. Karavan Trailers, Inc., 175 F.3d 1356, 1359 (Fed. Cir. 1999) (en banc in relevant part). The law of the Eighth Circuit seemed the appropriate law to consider, but the Federal Circuit applied its own law because its jurisdiction was implicated. See Litecubes, 523 F.3d at 1366. The court did note it would reach the same conclusion if it applied Eighth Circuit law because that circuit had yet to decide the question. Id. at 1366 n. 15 .

58. See, e.g., Michael Grecco Prods., Inc. v. NetEase Info. Tech. Corp., No. 18-3119 DSF (RAOX), 2018 WL 6443083, at*2 n.1 (C.D. Cal. Aug. 28, 2018); Int'l Acad. of Bus. \& Fin. Mgmt., Ltd. v. Mentz, No. 12-CV-00463-CMA-BNB, 2013 WL 212640, at*8 (D. Colo. Jan. 18, 2013); Shropshire v. Canning, 809 F. Supp. 2d 1139, 1144 (N.D. Cal. 2011); Zimnicki v. Gen. Foam Plastics Corp., No. 09 C 2132, 2010 WL 3941869, at *2 (N.D. Ill. Oct. 4, 2010); Wood v. Houghton Mifflin Harcourt Publ'g Co., 569 F. Supp. 2d 1135, 1139 (D. Colo. 2008) ("Given the Supreme Court's language in Arbaugh, this Court finds the Federal Circuit's approach and conclusion persuasive.”).

59. Hutson v. Notorious B.I.G., LLC, No. 14-CV-2307 (RJS), 2015 WL 9450623, at*6 (S.D.N.Y. Dec. 22, 2015); Rundquist v. Vapiano SE, 798 F. Supp. 2d 102, 123 (D.D.C. 2011).

60. 17 U.S.C. $\S 106(1)-(6)$. 
these rights to acts within the United States. ${ }^{61}$ The courts, however, have articulated a strong territorial principle. ${ }^{62}$

While courts parrot the language that U.S. copyright law does not extend beyond the territorial United States ${ }^{63}$ there have been efforts to use U.S. copyright law to control activity in other countries. The most famous of these cases involves an effort to use the right to authorize various activities to control foreign acts. ${ }^{64}$ In these scenarios, the act of authorization took place within the United States, but the particular acts, such as making a copy or performing the work, took place outside of the United States. For example, would a non-right holder's authorization in the United States to reproduce a copyrighted book in Hungary constitute infringement of a U.S. copyright? Prior to the Supreme Court's recent cases, the courts split on this issue.

The seminal case on this issue is the Ninth Circuit's en banc decision in Subafilms, Ltd. v. MGM-Pathe Communications Co. ${ }^{65}$ In Subafilms, the court concluded that domestic authorization of foreign activities that would violate $\S 106$ if performed domestically was not copyright infringement under the Copyright Act. The court reasoned that the "to authorize" language of $\S 106$ "was not meant to create a new form of liability for 'authorization' that was divorced completely from the legal consequences of authorized conduct, but was intended to invoke the preexisting doctrine of contributory infringement. ${ }^{" 66}$ Contributory infringement requires an act of direct infringement, which is absent when the authorized activity is outside of the United States. ${ }^{67}$ Consequently, the court held that domestic authorization of exclusively foreign activities does not constitute U.S. copyright infringement.

A prerequisite of this holding, though, is that foreign activity does not infringe the U.S. copyright. In other words, it requires a strict territorial view of U.S. copyright law. The court, therefore, explored this question as well. Drawing on the presumption against extraterritoriality, the court concluded that " $[t]$ here is no clear expression of congressional intent in either the 1976 Act or other relevant enactments to alter the preexisting extraterritoriality doctrine." ${ }^{, 68}$ The court noted that Congress

61. The statute's silence on its territorial reach contrasts sharply with the general infringement provision under the Patent Act, which specifically notes the acts must be within the United States. See 35 U.S.C. § 271(a). As discussed infra, the Patent Act contains infringement provisions that do contemplate some extraterritorial scope. See id. § 271(f), (g).

62. See, e.g., Liberty Toy Co. v. Fred Silber Co., 149 F.3d 1183 (6th Cir. 1998); Allarcom Pay Television, Ltd. v. Gen. Instrument Corp., 69 F.3d 381, 387 (9th Cir. 1995); Update Art, Inc. v. Modiin Publ'g, Ltd., 843 F.2d 67, 73 (2d Cir. 1988).

63. See, e.g., L.A. News Serv. v. Reuters Television Int'1, Ltd., 149 F.3d 987, 990 (9th Cir. 1998), as amended on denial of reh'g and reh'g en banc (Aug. 25, 1998) ("It is settled that the Copyright Act does not apply extraterritorially.”); Robert Stigwood Grp. Ltd. v. O’Reilly, 530 F.2d 1096, 1101 (2d Cir. 1976); Capitol Recs. v. Mercury Recs. Corp., 221 F.2d 657, 662 (2d Cir. 1955).

64. Subafilms, Ltd. v. MGM-Pathe Commc'ns Co., 24 F.3d 1088 (9th Cir. 1994) (en banc).

65. Id.

66. Id. at 1092

67. Id. at 1094 ("To hold otherwise would produce the untenable anomaly, inconsistent with the general principles of third party liability, that a party could be held liable as an infringer for violating the 'authorization' right when the party that it authorized could not be considered an infringer under the Copyright Act.").

68. Id. at 1096 . 
had provided some quasi-extraterritorial protection against the importation of copyrighted goods. ${ }^{69}$ Thus, if Congress wanted to provide protection over extraterritorial activities, it could have amended the Copyright Act to do so. ${ }^{70}$ The Ninth Circuit held that there is no infringement even if the foreign activities generate some sort of effect within the United States, particularly where there would be a risk of clash with foreign law. ${ }^{71}$ Indeed, the court viewed the potential for conflict as "decisive."72

Subafilms has its critics. ${ }^{73}$ Commentators have noted it is contrary to the clear text of the statute, which treats authorization as an independent right and not merely a codification of contributory infringement. ${ }^{74}$ Some have argued that the Subafilms interpretation of the authorization right arguably is in tension with the Supreme Court's view. ${ }^{75}$ In Sony Corp. v. Universal City Studios, the Court recognized that "the lines between direct infringement, contributory infringement, and vicarious liability are not clearly drawn." 76 The Court nevertheless described the authorization right as a separate form of direct infringement and not a form of indirect infringement: "An infringer is not merely one who uses a work without authorization by the copyright owner, but also one who authorizes the use of a copyrighted work without actual authority from the copyright owner." "77 If the act of authorization is an independent form of infringement, then it is not clear that the acts authorized must take place within the United States. ${ }^{78}$ The authorization right, therefore, is not simply a placeholder for contributory infringement. Another commentator has argued that there is little support in the legislative history for this conclusion. ${ }^{79}$

69. Id.

70. Id.

71. Id. at $1096-97$

72. Id. at 1097

73. See generally Nathan R. Wollman, Maneuvering Through the Landmines of Multi-territorial Copyright Litigation: How To Avoid the Presumption Against Extraterritoriality When Attempting To Recover for the Foreign Exploitation of U.S. Copyrighted Works, 104 W. VA. L. REV. 343, 374-76 (2002) (cataloging critiques).

74. John Patrick Kelsh, Note, Subafilms, Ltd. v. MGM-Pathe Communications Co., the Berne Convention, and the Extraterritorial Application of the Copyright Act, 90 NW. U. L. REV. 1839, 1846 (1996) ("The text of the statute offers no basis for the argument that Congress added the words "to authorize' to the text of the statute for the sole purpose of clarifying the doctrine of contributory infringement.").

75. Id. at 1849

76. Sony Corp. of Am. v. Universal City Studios, Inc., 464 U.S. 417, 435 n.17 (1984) (quoting Universal City Studios, Inc. v. Sony Corp. of Am., 480 F. Supp. 429, 457-58 (C.D. Cal. 1979)).

77. Id.

78. See Kelsh, supra note 74, at 1849 ("If this reading is correct, it is irrelevant whether the authorization is for actions that take place overseas or whether the authorization is ever acted on at all. Extraterritoriality need not be invoked. An illegitimate authorization is a violation in and of itself, and the copyright owner is entitled to any resulting damages.").

79. Phanesh Koneru, The Right "To Authorize" in U.S. Copyright Law: Questions of Contributory Infringement and Extraterritoriality, 37 IDEA 87, 94 (1996). 
Courts split over the Ninth Circuit's holding in Subafilms, with some following Subafilms ${ }^{80}$ and others rejecting it. ${ }^{81}$ One district court criticized the Ninth Circuit for ignoring the modern economic realities of a global marketplace. ${ }^{82}$ Another concluded that treating authorization of foreign acts as a form of domestic infringement is more consistent with the present state of our technology. ${ }^{83}$ This split has arisen between the Ninth Circuit and various district courts, however. Prior to the Supreme Court's recent involvement in the presumption against extraterritoriality, no other circuit court had directly addressed the issue. ${ }^{84}$

\section{Copyright Infringement Damages and the Predicate Act Doctrine}

A final scenario that has arisen is the ability of a U.S. copyright holder to obtain damages for foreign activity that flows from an act of domestic infringement. This scenario is different from Subafilms in that, there, the court concluded there was no domestic act of infringement. Under this scenario, the question is what damages are available for foreign activity that, by definition, is itself non-infringing but flows from a proven, predicate act of domestic infringement.

Numerous circuit courts have allowed damages for foreign activity under this scenario. The Second Circuit's allowance of such damages dates back to Sheldon v. Metro-Goldwyn Pictures Corp. in 1939. ${ }^{85}$ In Sheldon, the Second Circuit permitted recovery for overseas exhibition of a copy of a movie made in the United States, concluding:

The plaintiffs acquired an equitable interest in [the copies] as soon as they were made, which attached to any profits from their exploitation, whether in the form of money remitted to the United States, or of increase in the value of shares of foreign companies held by the defendants. We need not decide whether the law of those countries where

80. See, e.g., Illustro Sys. Int'l, LLC v. Int'l Bus. Machines Corp., No. CIV.A. 3:06-CV-1969-L, 2007 WL 1321825, at*13 (N.D. Tex. May 4, 2007) ("The court declines to follow the courts holding the minority view and rather follows the rule that extraterritorial acts of infringement do not violate federal copyright law.").

81. See, e.g., Curb v. MCA Recs., Inc., 898 F. Supp. 586, 595 (M.D. Tenn. 1995) ("Under this view, a phone call to Nebraska results in liability; the same phone call to France results in riches. In a global marketplace, it is literally a distinction without a difference.").

82. Id.

83. Expediters Int'l of Wash., Inc. v. Direct Line Cargo Mgmt. Servs., Inc., 995 F. Supp. 468, $476-$ 77 (D.N.J. 1998) ("This Court agrees with Curb's literal interpretation of Section 106 . . . Furthermore, the Court appreciates the policy observations set forth in Curb, which appear more closely adapted to our modern age of telefaxes, Internet communication, and electronic mail systems.").

84. One circuit court distinguished Subafilms. See Liberty Toy Co., Inc. v. Fred Silber Co., No. 97-3177, 1998 WL 385469, at *4 (6th Cir. June 29, 1998) ("This court finds that Subafilms is distinguishable, because in the instant case, we are not dealing exclusively with acts that occurred entirely abroad."). Since the Supreme Court's activity, one circuit court has agreed with Subafilms. See Geophysical Serv., Inc. v. TGS-NOPEC Geophysical Co., 850 F.3d 785, 799 (5th Cir. 2017) ("We believe that this structure supports the conclusion that 'to do' and 'to authorize' refer to direct and contributory infringement, respectively, but that infringement in either case must be predicated on one of the listed exclusive rights.").

85. Sheldon v. Metro-Goldwyn Pictures Corp., 106 F.2d 45, 52 (2d Cir. 1939), aff'd, 309 U.S. 390 (1940). See also L.A. News Serv. v. Reuters Television Int'1, Ltd., 149 F.3d 987, 992 (9th Cir. 1998) (recognizing Sheldon as the start of this line of cases). 
the negatives were exploited, recognized the plaintiffs' equitable interest; we can assume arguendo that it did not, for, as soon as any of the profits so realized took the form of property whose situs was in the United States, our law seized upon them and impressed them with a constructive trust, whatever their form. ${ }^{86}$

The Second Circuit has continued to afford such relief, ${ }^{87}$ though it has limited the doctrine. ${ }^{88}$ Other circuits have followed this approach. ${ }^{89}$

One could view such an award of damages as an afront to the territoriality principle. While these acts may flow from the domestic infringement, the activity took place in a foreign jurisdiction. Awarding damages for such activity is a way of regulating activity within the foreign country, which could contravene the sovereign interest of that country. ${ }^{90}$ But the courts have ignored this reality in a conspicuous way: They have failed to address the presumption against extraterritoriality in awarding such damages. The courts have granted this relief, perhaps believing that any issues of extraterritoriality were limited to the liability context. Once there has been an act of domestic infringement, concerns about extraterritoriality disappear.

The state of extraterritoriality in the copyright context prior to the Supreme Court's recent decisions was complicated, with a patchwork of protection afforded by the courts. While the courts did engage with the presumption in the context of domestic authorization, concerns of extraterritoriality - and any formal use of the presumption-did not arise in the context of damages under the predicate act doctrine. Additionally, unlike trademark law, the courts have not expressly considered comity as relevant in assessing whether to extend the reach of the Copyright Act to activities outside of the United States.

\section{Patent Law}

In contrast to copyright and trademark law, assessing the state of extraterritoriality doctrine in patent law is easier, even if the issues remain thorny. The Federal Circuit

86. Sheldon, 106 F.2d at 52.

87. See, e.g., Update Art, Inc. v. Modiin Publ'g, Ltd., 843 F.2d 67, 73 (2d Cir. 1988) ("There is an exception - when the type of infringement permits further reproduction abroad - such as the unauthorized manufacture of copyrighted material in the United States.").

88. See, e.g., Robert Stigwood Grp. Ltd. v. O'Reilly, 530 F.2d 1096, 1101 (2d Cir. 1976) ("It is only when the type of infringement permits further reproduction abroad that its exploitation abroad becomes the subject of a constructive trust.").

89. See, e.g., Tire Eng'g \& Distrib., LLC v. Shandong Linglong Rubber Co., 682 F.3d 292, 308 (4th Cir. 2012) ("We join our sister circuits that have adopted the predicate-act doctrine."); L.A. News Serv. v. Reuters Television Int'1, Ltd., 149 F.3d 987, 992 (9th Cir. 1998) ("We therefore hold that LANS is entitled to recover damages flowing from exploitation abroad of the domestic acts of infringement committed by defendants."), as amended on denial of reh'g and reh'g en banc (Aug. 25, 1998); see also IMAPizza, LLC v. At Pizza Ltd., 965 F.3d 871, 878 (D.C. Cir. 2020) (recognizing that the Second, Fourth, and Ninth Circuits use the predicate-act test but not deciding whether to embrace it).

90. See Timothy R. Holbrook, Extraterritoriality and Proximate Cause After WesternGeco, 21 YALE J.L. \& TECH. 189, 206 (2019) [hereinafter Holbrook, Proximate Cause]. 
is the sole arbiter of patent law at the appellate level, save for the Supreme Court. As such, the law develops in a centralized fashion, with the Federal Circuit resolving splits at the district court level or its own intra-circuit splits. But the law is generally clear, with few to no splits with other federal appellate courts.

Patent law has generally been viewed as the most territorial of the three forms of intellectual property. ${ }^{91}$ Historically, patent law was more rooted in the tangible and industrial, which made identifying the locus of infringement easier. ${ }^{92}$ The modern era has changed this dynamic, with digital technologies and global supply chains that cross and transcend national boundaries. More recent amendments to the Patent Act have afforded patentees with some extraterritorial protection. ${ }^{93}$ Moreover, notwithstanding some seemingly clear textual language in the Patent Act, the Federal Circuit has afforded extraterritorial protection in other contexts, albeit inconsistently. This subsection explores the judicial interpretations and statutory provisions that have dealt with issues of extraterritoriality in patent law. ${ }^{94}$

As with trademark law, the Supreme Court has articulated strong views about the territorial limits of patent law. In contrast with trademark law, however, the Court has stressed that U.S. patents are territorially limited. ${ }^{95}$ Prior to the Court's recent reengagement with both patent law and the presumption against extraterritoriality, ${ }^{96}$ the seminal case was Deepsouth Packing Co. v. Laitram Corp. ${ }^{97}$ In that case, the accused infringer had made all components of the patented shrimp deveiner within

91. See Chisum, supra note 4 , at 605 .

92. Cf. Timothy R. Holbrook, Method Patent Exceptionalism, 102 IowA L. REV. 1001, 1009-13 (2017) [hereinafter Holbrook, Method Patent] (discussing shift in technology from industrial to information age).

93. See 35 U.S.C. § 271(f), (g). See generally Timothy R. Holbrook, Territoriality Waning? Patent Infringement for Offering in the United States to Sell an Invention Abroad, 37 U.C. DAVIS L. REV. 701, 720-22 (2004) [hereinafter Holbrook, Territoriality Waning?] (discussing the history of these two provisions).

94. The focus of this analysis is on liability provisions and damages. At times, courts have alluded to extraterritoriality in other contexts. For example, in determining whether the sale of the patented device in a foreign country by the patentee exhausts the patent rights, the Supreme Court referenced the territoriality principle. See Impressions Prods. v. Lexmark Int'l, Inc., 137 S. Ct. 1523 (2017). The Court, though, did not formally engage with the presumption against extraterritoriality, nor with the potential extraterritorial consequences if foreign sales exhausted the U.S. patent. This scenario is peculiar because the Court's embrace of an international exhaustion regime will have considerable collateral consequences for foreign activity and perhaps should be deemed a form of extraterritorial regulation. See generally Holbrook, What Counts?, supra note 51. For the copyright context, see supra note 51.

95. See, e.g., Dowagiac Mfg. Co. v. Minn. Moline Plow Co., 235 U.S. 641, 650 (1915) ("The right conferred by a patent under our law is confined to the United States and its territories, and infringement of this right cannot be predicated of acts wholly done in a foreign country." (citation omitted)); Brown v. Duchesne, 60 U.S. (19 How.) 183, 196-97 (1856) ("This view of the subject, however, presupposes that the patent laws embrace improvements on foreign ships, lawfully made in their own country, which have been patented here. But that is the question in controversy. And the court is of opinion that cases of that kind were not in the contemplation of Congress in enacting the patent laws, and cannot, upon any sound construction, be regarded as embraced in them.").

96. See Timothy R. Holbrook, Boundaries, Extraterritoriality, and Patent Infringement Damages, 92 Notre DAME L. REV. 1745, 1746-48 (2017) [hereinafter Holbrook, Boundaries] (discussing the Supreme Court's reengagement with both patent law and extraterritoriality).

97. Deepsouth Packing Co., Inc., v. Laitram Corp., 406 U.S. 518 (1972). 
the United States but never assembled them into the patented device. ${ }^{98}$ Instead, the accused infringer shipped the unassembled machines overseas, where they were assembled fairly easily. ${ }^{99}$

The Supreme Court recognized that making or using a product outside of the United States is not an act of infringement. ${ }^{100}$ The Court reasoned: "The sales question thus resolves itself into the question of manufacture: Did Deepsouth 'make' (and then sell) something cognizable under the patent law as the patented invention, or did it 'make' (and then sell) something that fell short of infringement?"101 The Court concluded that the invention had not been made and thus had not been sold in the United States, so there was no infringement. ${ }^{102}$ The Court emphasized that "[o]ur patent system makes no claim to extraterritorial effect; 'these acts of Congress do not, and were not intended to, operate beyond the limits of the United States,' and we correspondingly reject the claims of others to such control over our markets." 103 As to protection in foreign markets, Congress intended for patent holders to "seek it abroad through patents secured in countries where [their] goods are being used," and the Court questioned why the patentee had not done so in this case, given that it held foreign patents. ${ }^{104}$

Even with this doctrinal backdrop, issues of extraterritoriality in patent law persist.

\section{Is Extraterritoriality Jurisdictional or Part of the Merits?}

One issue that the courts had to confront in the copyright and trademark context is whether territorial limits are jurisdictional in nature. This issue was quickly put to bed in the patent context by the Federal Circuit, which concluded that issues of extraterritoriality were part of the merits and not jurisdictional in nature. ${ }^{105}$

98. Id. at 519 .

99. Id. at 524 ("Deepsouth seeks judicial approval, expressed through a modification or interpretation of the injunction against it, for continuing its practice of shipping deveining equipment to foreign customers in three separate boxes, each containing only parts of the $13 / 4$-ton machines, yet the whole assemblable in less than one hour. The company contends that by this means both the 'making' and the 'use' of the machines occur abroad and Laitram's lawful monopoly over the making and use of the machines throughout the United States is not infringed.").

100. Id. at 527 .

101. Id.

102. Id. at 528 ("We cannot endorse the view that the 'substantial manufacture of the constituent parts of (a) machine' constitutes direct infringement when we have so often held that a combination patent protects only against the operable assembly of the whole and not the manufacture of its parts.").

103. Id. at 531 (quoting Brown v. Duchesne, 60 U.S. (19 How.) 183, 195 (1856)).

104. Id.

105. Litecubes, LLC v. N. Light Prods., Inc., 523 F.3d 1353, 1365 (Fed. Cir. 2008) ("Consistent with this understanding, while our court has never addressed the issue explicitly, we have been able to find no instance in which this court has treated the question of whether allegedly infringing activity took place within the United States as a question of subject matter jurisdiction.”). 


\section{Patent Infringement Determinations}

Section 271(a) of the Patent Act lays out the basic exclusive rights afforded patent owners. ${ }^{106}$ The provision defines infringement as the making, using, selling, or offering to sell the invention within the United States or the importation of the invention into the United States. ${ }^{107}$ The territorial limits of the provision, therefore, are explicit. With such language, one would think these exclusive rights would not afford much, if any, extraterritorial protection. But that intuition would be incorrect.

The Federal Circuit held that the use of a patented system that is in part in the United States and in part outside can infringe a U.S. patent. In NTP, Inc. v. Research In Motion, the court found that the Blackberry system infringed a U.S. patent even though part of the system was in Canada. ${ }^{108}$ The court concluded that the Blackberry users in the United System both controlled the system and received the benefit of such use within the United States. ${ }^{109}$ Interestingly, the court reached a different conclusion for the use of the patented method. ${ }^{110}$ The court created a strict territorial rule requiring that each step of the method be performed within the United States. ${ }^{111}$ Because one step occurred outside of the United States, there was no infringement of the patented method, creating an atextual distinction between system and method claims. ${ }^{12}$

The Federal Circuit has also afforded extraterritorial reach for infringement through an offer to sell the patented invention. In Transocean Offshore Deepwater Drilling, Inc. v. Maersk Contractors USA, Inc., the Federal Circuit held that the location of sale contemplated in the offer governed the locus of infringement, regardless of the location of the offer. ${ }^{113}$ In Transocean, negotiations to purchase the patented drilling rig had taken place in Scandinavia. ${ }^{114}$ The sale, if consummated, was to be delivered and performed within the United States. ${ }^{115}$ The court, therefore, held that there was an infringing offer to sell the invention in the United States. ${ }^{116}$ In adopting this rule, the Federal Circuit referenced the presumption against extraterritoriality but otherwise did not readily engage with the potential extraterritorial consequences of its rule. ${ }^{117}$

The Transocean rule expands the extraterritorial scope of U.S. patent rights significantly because someone could infringe without any contact with the United

\footnotetext{
106. 35 U.S.C. $\$ 271(a)$.

107. Id.

108. NTP, Inc. v. Rsch. In Motion, Ltd., 418 F.3d 1282, 1317 (Fed. Cir. 2005).

109. Id.

110. Id. at $1317-18$

111. Id. at 1318

112. See Holbrook, Method Patent, supra note 92, at 1056-58 (criticizing this approach and arguing for a single approach for infringing uses of both methods and systems).

113. Transocean Offshore Deepwater Drilling, Inc. v. Maersk Contractors USA, Inc., 617 F.3d 1296, 1309 (Fed. Cir. 2010) ("The focus should not be on the location of the offer, but rather the location of the future sale that would occur pursuant to the offer.").

114. Id. at 1310

115. Id.

116. Id.

117. Id. at 1309 .
} 
States. ${ }^{118}$ Suppose that all negotiations take place outside of the United States, resulting in a formal offer to sell the invention in the United States, but that offer is declined. No activity would take place in the United States. Yet, there would be infringement in the United States because an offer does not have to be accepted in order to infringe the patent.

The Federal Circuit has also provided extraterritorial protection against acts of inducing infringement. As a textual matter, 35 U.S.C. § 271(b)'s prohibition on actively inducing others to infringe a patent contains no territorial limits. ${ }^{119}$ This contrasts with its sibling provision, §271(c), which defines contributory infringement. ${ }^{120}$ Section 271(c) lacked territorial limits until Congress amended it in 1994. ${ }^{121}$ But Congress failed to amend $\S 271(\mathrm{~b})$. While perhaps accidental, ${ }^{122}$ the failure to amend $\S 271(\mathrm{~b})$ creates a textual argument that Congress did intend $\S 271$ (b) to have some extraterritorial scope. ${ }^{123}$ The Federal Circuit has confirmed this extraterritorial reach by permitting acts outside of the United States to be infringing if they ultimately induce a domestic act of infringement. ${ }^{124}$

Beyond these judicial interpretations, Congress statutorily afforded extraterritorial protection to patents by subsequent amendment to the Patent Act. Although Deepsouth articulated a strict territorial rule, Congress eventually overturned the holding by adopting 35 U.S.C. $\S 271(\mathrm{f})(1)$ and (2). ${ }^{125} \quad$ Paragraph (1) overturns Deepsouth by defining the exportation of all or a substantial portion of the components of the invention with the intent to induce the assembly of the invention

118. For a two-by-two matrix exploring all the permutations of this ambiguity, see Timothy R. Holbrook, Territoriality and Tangibility after Transocean, 61 EMORY L.J. 1087 (2012) [hereinafter Holbrook, Tangibility].

119. The full text of that provision states merely: "Whoever actively induces infringement of a patent shall be liable as an infringer.” 35 U.S.C. § 271(b).

120. Subsections 271(b) and (c) are codifications of the common law forms of indirect infringement, with contributory infringement being the most common and inducement remaining somewhat of a catchall provision. See Hewlett-Packard Co. v. Bausch \& Lomb Inc., 909 F.2d 1464, 1469 (Fed. Cir. 1990); see also Timothy R. Holbrook, The Supreme Court's Quiet Revolution in Induced Patent Infringement, 91 NOTRE DAME L. REV. 1007, 1010 (2016).

121. Chisum, supra note 4, at 615 (discussing extraterritorial reach of $\S 271$ (c) prior to the 1994 amendments).

122. See id. ("There appears to be no policy reason for restricting section 271(c) in this fashion. The change may have been a grammatical indiscretion.").

123. The Federal Circuit had tried to make $\S 271$ (b) an independent form of infringement, divorced from infringement under $\S 271(\mathrm{a})$, an effort rejected by the Supreme Court. Akamai Techs., Inc. v. Limelight Networks, Inc., 692 F.3d 1301, 1306 (Fed. Cir. 2012) (en banc) ("To be clear, we hold that all the steps of a claimed method must be performed in order to find induced infringement, but that it is not necessary to prove that all the steps were committed by a single entity."), rev'd, 572 U.S. 915 (2014). The Federal Circuit's approach to induced infringement would have dramatically expanded $\S 271(\mathrm{~b})$ 's extraterritorial reach, a likely unintended consequence. See generally Timothy R. Holbrook, The Potential Extraterritorial Consequences of Akamai, 26 EMORY INT'L L. REV. 499 (2012).

124. See Merial Ltd. v. Cipla Ltd., 681 F.3d 1283, 1302-03 (Fed. Cir. 2012). Technically the court was addressing a contempt finding after the district court had entered a permanent injunction, but the court nevertheless confirmed the extraterritorial reach of $\S 271(\mathrm{~b})$.

125. See 35 U.S.C. § 271(f). See also Holbrook, Territoriality Waning?, supra note 93, at 721 (describing the history of this provision). 
abroad as infringement. ${ }^{126}$ Paragraph (2) goes a bit further, defining infringement as the exportation of a component of the patented invention having no substantial noninfringing use, with the intent that the component be combined overseas to make the invention. ${ }^{127}$ By focusing on exportation, and thus foreign markets, $\S 271$ (f) is by design extraterritorial in nature, though there is the domestic hook of supplying the components from the United States.

The Federal Circuit's interpretation of this provision has been somewhat mixed in terms of its extraterritorial reach. The Federal Circuit made clear that the invention need not actually be assembled outside of the United States for there to be infringement, expanding the scope of the provision. ${ }^{128}$ In early cases involving software patents, the Federal Circuit offered expansive interpretations of the statute. $^{129}$ On the other hand, the Federal Circuit relied in part on the presumption to hold that $\S 271(\mathrm{f})$ does not apply to claims to methods, reducing the provision's scope. ${ }^{130}$

Nevertheless, likely because of the extraterritorial aspects of $\S 271$ (f), it has been a favorite of the Supreme Court. ${ }^{131}$ The Court has reviewed this provision three times since 2007. ${ }^{132}$ It rejected the Federal Circuit's expansive interpretation of "component" and "supplying" in the context of software patents in Microsoft Corp. v. AT \& T Corp. ${ }^{133}$ The Court recognized that " $\$ 271(\mathrm{f})$ is an exception to the general rule that our patent law does not apply extraterritorially," so the Court had to "resist giving the language in which Congress cast $§ 271(\mathrm{f})$ an expansive interpretation." Any such adjustments to the provision are left to Congress. ${ }^{135}$

126. 35 U.S.C. $§ 271(\mathrm{f})(1)$. See Keith Bradley, Note, The Ghost Is the Machine: Protection of Process Patents Under 35 U.S.C. § 271(f), 15 TeX. InTELL. ProP. L.J. 123, 127 (2006) (“Section 271(f) originated as Congress's response to Deepsouth.").

127. 35 U.S.C. $\S 271(\mathrm{f})(2)$.

128. Waymark Corp. v. Porta Sys. Corp., 245 F.3d 1364, 1368 (Fed. Cir. 2001); see Bradley, supra note 126, at 131 ("After Waymark, U.S. patents have, in this sense, more reach outside the United States than within.").

129. AT \& T Corp. v. Microsoft Corp., 414 F.3d 1366, 1370 (Fed. Cir. 2005) (“Accordingly, for software 'components,' the act of copying is subsumed in the act of 'supplying,' such that sending a single copy abroad with the intent that it be replicated invokes $\S 271$ (f) liability for those foreign-made copies."), rev'd, 550 U.S. 437 (2007); Eolas Techs. Inc. v. Microsoft Corp., 399 F.3d 1325, 1341 (Fed. Cir. 2005) (holding "that section 271(f)(1)'s 'components' include software code on golden master disks."). See Andrew F. Knight, Software, Components, and Bad Logic: Recent Interpretations of Section 271(f), 87 J. PAT. \& TRADEMARK OFF. SOC'Y 493, 493 (2005) ("In other words, current precedent, if meticulously and correctly followed, spells the demise of U.S. patent law territoriality.").

130. Cardiac Pacemakers, Inc. v. St. Jude Med., Inc., 576 F.3d 1348, 1365 (Fed. Cir. 2009) (en banc in relevant part); see Elizabeth T. Joseph, Apocalypse Soon: How the Implementation of Web Services Changes the Game for Extraterritoriality, 36 J. CORP. L. 239, 244 (2010) (referring to Cardiac Pacemakers as "A Return to the Narrowing of $\S 271$ (f)").

131. See Timothy R. Holbrook, Explaining the Supreme Court's Interest in Patent Law, 3 IP THEORY 62, 72 (2012) [hereinafter Holbrook, Supreme Court's Interest].

132. WesternGeco LLC v. ION Geophysical Corp., 138 S. Ct. 2129 (2018); Life Techs. Corp. v. Promega Corp., 137 S. Ct. 734 (2017); Microsoft Corp. v. AT \& T Corp., 550 U.S. 437 (2007).

133. 550 U.S. 437 (2007).

134. Id. at 442 .

135. Id. 
Section 271(g) of the Patent Act also affords extraterritorial protection for patented processes. If someone uses a patented process outside of the United States but ultimately "imports into the United States or offers to sell, sells, or uses within the United States" the product of that process, then that party is liable for patent infringement. The Federal Circuit has interpreted this provision to cover circumstances where the steps of the method are performed by different actors, expanding the scope of the statute. ${ }^{136}$

In terms of liability, the courts have been willing to afford extraterritorial reach to the seemingly most territorial form of intellectual property, patent law. In so doing, the Federal Circuit's reliance on the presumption against extraterritoriality has been, at best, mixed.

\section{Patent Infringement Damages}

Under the predicate act doctrine, a copyright owner can obtain damages for foreign activity if it flows from a domestic act of infringement. Patent law has confronted the analogous situation. The Federal Circuit, however, reached the opposite conclusion, precluding damages under these worldwide theories of patent damages. In a trilogy of cases, the Federal Circuit adopted a strict territorial rule for awarding such damages. ${ }^{137}$

In Power Integrations, Inc. v. Fairchild Semiconductor International, Inc., the Federal Circuit denied damages based on the patent holder's theory of lost profits for forgone foreign sales, even if they were the foreseeable result of the domestic act of infringement under 35 U.S.C. $§ 271$ (a). ${ }^{138}$ The court reasoned:

Power Integrations' "foreseeability" theory of worldwide damages sets the presumption against extraterritoriality in interesting juxtaposition with the principle of full compensation. Nevertheless, Power Integrations' argument is not novel, and in the end, it is not persuasive. Regardless of how the argument is framed under the facts of this case, the underlying question here remains whether Power Integrations is entitled to compensatory damages for injury caused by infringing activity that occurred outside the territory of the United States. The answer is no. ${ }^{139}$

Subsequently, in Carnegie Mellon University v. Marvell Technology Group., Ltd., the Federal Circuit extended this reasoning to reasonable royalty damages for acts outside of the United States resulting from a domestic act of infringement. ${ }^{140}$ In the

136. Syngenta Crop Prot., LLC v. Willowood, LLC, 944 F.3d 1344, 1362 (Fed. Cir. 2019).

137. See Bernard Chao, Patent Law's Domestic Sales Trap, 93 DenV. L. ReV. OnLINE 87 (2016); Sapna Kumar, Patent Damages Without Borders, 25 TEX. INTELL. PROP. L.J. 73, 92-95 (2017). Some of these cases arose during the Supreme Court's engagement with the presumption against extraterritoriality. As such, while addressed in this Article in advance of the discussion of the Supreme Court's engagement, these cases overlapped with the Supreme Court's re-engagement with the presumption. See, e.g., Power Integrations, Inc. v. Fairchild Semiconductor Int'l, Inc., 711 F.3d 1348, 1372 (Fed. Cir. 2013) (discussing Morrison). But these cases were decided before the Supreme Court's elaboration of the methodology under RJR Nabisco and still show a lack of concern for the presumption.

138. 711 F.3d 1348 (Fed. Cir. 2013).

139. Id. at 1371 .

140. Carnegie Mellon Univ. v. Marvell Tech. Grp., Ltd., 807 F.3d 1283, 1309 (Fed. Cir. 2015). 
third case in the trilogy, WesternGeco LLC. v. ION Geophysical Corp., the Federal Circuit held that a patentee could not get lost profits under § 271(f) for the forgone sales of services for using the patented invention on the high seas. ${ }^{141}$ The court drew on both Power Integrations and the presumption in reaching this conclusion. ${ }^{142}$ In contrast to its liability doctrines and to copyright law, the Federal Circuit embraced a strong view of the presumption in curtailing the availability of damages for foreign activities that were the result of domestic acts of infringement.

The Federal Circuit's development of the extraterritorial reach of U.S. patents has been somewhat inconsistent, with the court at times affording such protection even in the face of explicit territorial limits in the statute. In the liability context, while the Federal Circuit has invoked the presumption against extraterritoriality, the presumption has had little impact on the court's analysis. Yet, with respect to damages, the court drew a strict territorial line, justified in part on the presumption. This approach to damages also conflicts with the approach articulated in copyright law.

As with other courts' copyright cases, and unlike other trademark cases, the Federal Circuit has also failed to account for potential conflicts of law in its patentrelated extraterritoriality analysis. This omission is particularly surprising given the precedent of the U.S. Court of Claims, one of the Federal Circuit's predecessor courts. That court faced a case similar to $N T P,{ }^{143}$ where a radio navigation system was controlled in the United States but one of the stations was in Norway. ${ }^{144}$ The Court of Claims concluded that system was used in the United States and thus infringed the relevant patent. ${ }^{145}$ The Federal Circuit derived its "control and beneficial use" test from Decca. ${ }^{146}$ But the court's embrace of Decca was incomplete. The Court of Claims also considered potential conflicts of law, ${ }^{147}$ consistent with the approach used by courts in trademark law. The Federal Circuit diverged from the binding precedent of its predecessor court and embraced an approach consistent with copyright but not trademark law.

The Federal Circuit's treatment of patent extraterritoriality was a mixed bag. It is unsurprising perhaps that the Supreme Court would use patent law to advance its

141. WesternGeco LLC v. ION Geophysical Corp.,791 F.3d 1340, 1354 (Fed. Cir. 2015), cert. granted, judgment vacated 136 S. Ct. 2486 (2016). While technically the case was vacated and remanded by the Supreme Court, the Federal Circuit reinstated its reasoning as to availability of damages outside of the United States. WesternGeco L.L.C. v. ION Geophysical Corp., 837 F.3d 1358, 1360 (Fed. Cir. 2016) ("On remand, we vacate the district court's judgment with respect to enhanced damages for willful infringement under 35 U.S.C. $\$ 284$ and reinstate our earlier opinion and judgment in all other respects."), rev'd 138 S. Ct. 2129 (2018), and opinion reinstated in part, 913 F.3d 1067, 1075 (Fed. Cir. 2019).

142. Id. at $1349-51$.

143. NTP, Inc. v. Rsch. In Motion, Ltd., 418 F.3d 1282 (Fed. Cir. 2005).

144. Decca Ltd. v. United States, 544 F.2d 1070, 1074 (Ct. Cl. 1976).

145. Id. at 1083.

146. NTP, 418 F.3d at 1317.

147. Decca, 544 F.2d at 1074 . 
interest in creating a standardized, formal approach to the presumption against extraterritoriality.

\section{THE TRANSFORMATION OF EXTRATERRITORIALITY BY THE SUPREME COURT TETRALOGY}

The presumption against extraterritoriality in the intellectual property context undeniably was a bit of a mess. There was little consistency across the various disciplines and, indeed, considerable variability and disagreement even within trademark, copyright, and patent regimes. The situation in intellectual property law was not unique. The courts' application of the presumption generally was inconsistent. The Supreme Court recognized this unsatisfying state of affairs. In a series of four cases, the Court began to clarify and formalize its approach to assessing the extraterritorial reach of U.S. law.

\section{A. The Supreme Court Gives the Presumption More Teeth in Morrison V. NATIONAL AUSTRALIA BANK}

The Supreme Court had dipped its toe into the extraterritorial waters in Microsoft Corp. v. AT \& T Corp. ${ }^{148}$ In that context, though, the Court was dealing with narrow issues surrounding a specialized patent infringement provision. Microsoft appears to have been a harbinger of the Supreme Court's future reengagement with the presumption. Three years after Microsoft, the Court addressed the presumption squarely in Morrison v. National Australia Bank Ltd. ${ }^{149}$

The issue presented was whether $\S 10(\mathrm{~b})$ of the Securities and Exchange Act applied to activity taking place in Australia. ${ }^{150}$ As a threshold matter, though, the Court addressed whether extraterritoriality in this context was jurisdictional or a merits issue, ${ }^{151}$ a question that courts have found vexing in the trademark and copyright contexts. ${ }^{152}$ The Supreme Court acknowledged that the appellate court and district court were following the relevant circuit-level precedent but nevertheless erred by viewing the question as jurisdictional. ${ }^{153}$

Turning to the merits, the Court held that $\S 10(\mathrm{~b})$ did not reach extraterritorial activities. ${ }^{154}$ The Court acknowledged that the courts had splintered on this issue, with commentators calling the courts" applications "unpredictable and inconsistent." 155 Instead of narrowly answering the question, however, the Supreme

148. Microsoft Corp. v. AT \& T Corp., 550 U.S. 437, 437 (2007). See Holbrook, Supreme Court's Interest, supra note 131, at 72 (discussing Microsoft as part of the Supreme Court's efforts to bring patent law into the mainstream). See also supra notes 136-140 and accompanying text.

149. Morrison v. Nat'1 Austl. Bank Ltd., 561 U.S. 247 (2010).

150. Id. at $250-51$.

151. Id. at $253-54$.

152. See supra notes 29-39 and accompanying text (trademark), and supra notes 52-62 and accompanying text (copyright)

153. Morrison, 561 U.S. at 253-54.

154. Id. at 265 .

155. Id. at 260 . 
Court took the opportunity to invigorate the presumption against extraterritoriality, noting that the presumption applies "in all cases" in order to "preserv[e] a stable background against which Congress can legislate with predictable effects."156 Somewhat hyperbolically, the Court suggested that, "[w]hen a statute gives no clear indication of an extraterritorial application, it has none." 157 Emphasizing the importance of the presumption, the Court noted that in effect, the presumption would be "a craven watchdog indeed if it retreated to its kennel whenever some domestic activity is involved in the case." 158

The Court did acknowledge what could be viewed as an exception to the presumption. It is possible that acts relevant to the focus of the statute took place within the United States, even if others were outside. In that situation, the conduct may yet fall within the scope of the statute even if some conduct was outside of the United States, regardless of the presumption. ${ }^{159}$ Ultimately the Court held that, in this case, the relevant acts were outside the scope of $\S 10(b)$.

\section{B. Expanding the Application of the Presumption in Kiobel V. Royal Dutch Petroleum Co.}

Morrison seemed to be a vehicle for the Supreme Court to ratchet up the import of the presumption against extraterritoriality, while also introducing the idea of the "focus" of a statute. It remained unclear, though, whether this discussion was meant to have wide applicability or whether it was directed simply to securities regulation. ${ }^{160}$ In short order, the Court made clear that Morrison spoke to more than just securities law.

In Kiobel v. Royal Dutch Petroleum Co., the Court addressed the Alien Tort Statute (ATS). ${ }^{161}$ Unlike most other statutes, the ATS "does not directly regulate conduct or afford relief"; instead, it permits "federal courts to recognize certain

156. Id. at 261 (footnote omitted).

157. Id. at 255. The Court clarified that this is not a "clear statement" rule. $I d$. at 265 ("But we do not say, as the concurrence seems to think, that the presumption against extraterritoriality is a "clear statement rule,' if by that is meant a requirement that a statute say 'this law applies abroad.' Assuredly context can be consulted as well.”) (internal citation omitted) (quoting id. at 278 (Stevens, J., concurring)). But see id. at 278 (Stevens, J., concurring) ("First, the Court seeks to transform the presumption from a flexible rule of thumb into something more like a clear statement rule.”).

158. Id. at 266 .

159. Id. See Dodge, supra note 1, at 1605-06 (calling Morrison's focus analysis "a significant departure from the traditional understanding of the presumption against extraterritoriality"). But see Lea Brilmayer, The New Extraterritoriality: Morrison v. National Australia Bank, Legislative Supremacy, and the Presumption Against Extraterritorial Application of American Law, 40 Sw. L. REV. 655, 663 (2011) ("The possibility that the presumption against extraterritorial application of a statute can be circumvented simply by declaring the presumption inapplicable creates a major loophole. Rather than undertaking a thankless (and probably fruitless) search for indications about what Congress wanted, a court need only decide that the presumption against extraterritoriality is inapplicable because the 'focus' of the substantive law in question is something that took place in the United States.").

160. Timothy R. Holbrook, Should Foreign Patent Law Matter?, 34 CAMPBELL L. REV. 581, 604 (2012) ("The question arises, then, as to how broadly applicable the language of Morrison is. Does Morrison represent a sweeping alteration to the presumption, creating close to a 'clear statement' rule requirement, or is it limited to the context of $\S 10(\mathrm{~b})$ of the securities law?").

161. Kiobel v. Royal Dutch Petroleum Co., 569 U.S. 108 (2013). 
causes of action based on sufficiently definite norms of international law."162 The ATS is "strictly jurisdictional" in nature. ${ }^{163}$ It does not create a cause of action but permits U.S. courts to hear cases rooted in these international norms.

The Court nevertheless held that the presumption against extraterritoriality applies to the ATS. While seemingly applying the presumption to a jurisdictional question, commentators have argued that the Court did no such thing, instead applying it to the causes of action underlying the ATS. ${ }^{164}$ In the case, Nigerian nationals residing in the United States attempted to sue Dutch, British, and Nigerian corporations under the ATS for acts occurring outside of the United States, so there was fairly little connection to the United States. ${ }^{165}$ The Court held that the presumption had not been rebutted because "all the relevant conduct took place outside the United States." 166 The Court further elaborated, though, that "even where the claims touch and concern the territory of the United States, they must do so with sufficient force to displace the presumption against extraterritorial application." 167

\section{Formalizing a Two-STEP Methodology in RJR Nabisco, INC. $v$. EUROPEAN COMMUNITY}

In applying Morrison in Kiobel, the Supreme Court made clear that its discussion in Morrison was not specific to securities regulations. Although the Court established some guideposts for analyzing the extraterritorial reach of U.S. law, it still had not formalized a methodology.

The Court made that move in RJR Nabisco, Inc. v. European Community. ${ }^{168}$ The issues in RJR Nabisco involved the extraterritorial scope of two provisions of the Racketeer Influenced and Corrupt Organizations Act (RICO): its substantive provisions in $\S 1962$ and its private right of action in $\S 1964(\mathrm{c}) .{ }^{169}$ The case involved allegations that "RJR Nabisco and numerous related entities ... participated in a global money-laundering scheme in association with various organized crime groups." $" 170$

The Court took the opportunity to elaborate a two-step framework for assessing the extraterritorial reach of a statute. At step one, a court should determine "whether the presumption against extraterritoriality has been rebutted-that is, whether the

162. Id. at 116 .

163. Id.

164. Id. ("But we think the principles underlying the canon of interpretation similarly constrain courts considering causes of action that may be brought under the ATS.”). See RESTATEMENT (FOURTH) OF FOREIGN RELATIONS LAW OF THE UNITED STATES $§ 404$ n.3 (AM. L. INST. 2018); Dodge, supra note 1, at 1620-23. The Supreme Court similarly refers to jurisdictional statutes in RJR Nabisco, Inc. v. Eur. Cmty., 136 S. Ct. 2090, 2101 ("We must ask this question regardless of whether the statute in question regulates conduct, affords relief, or merely confers jurisdiction."). This language has also been criticized as dictum and inaccurate by Professor Dodge and the Restatement.

165. Kiobel, 569 U.S. at 111-14.

166. Id. at 124 .

167. Id. at $124-25$.

168. RJR Nabisco, Inc. v. Eur. Cmty., 136 S. Ct. 2090 (2016).

169. Id. at 2099

170. Id. at 2098 . 
statute gives a clear, affirmative indication that it applies extraterritorially." ${ }^{\prime 171}$ Step one, therefore, is the classic presumption against extraterritoriality, an act of statutory interpretation that considers the statute and legislative history to divine Congress's views on the statute's territorial limits. As an act of statutory interpretation, step one is not fact dependent, and any conclusion can have precedential effect beyond a particular case. ${ }^{172}$

If the presumption has not been rebutted, however, the inquiry does not end. At step two, a court must "determine whether the case involves a domestic application of the statute ... by looking to the statute's 'focus." 173 Because the focus analysis considers the facts of the case vis-à-vis the statute, step two is factual in nature, limiting the precedential effect of any decision. ${ }^{174}$ The Court confirmed that this test is generalizable and applies to all statutes "regardless of whether the statute ... regulates conduct, affords relief, or merely confers jurisdiction." 175

Application of this methodology yielded mixed results in RJR Nabisco. As to the substantive provisions under $\S 1962$, the Court found the presumption rebutted at step one. The Court concluded, "Congress's incorporation of these (and other) extraterritorial predicates into RICO gives a clear, affirmative indication that $\S 1962$ applies to foreign racketeering activity — but only to the extent that the predicates alleged in a particular case themselves apply extraterritorially."176 The Court declined to discuss step two - the focus of the statute - given that it found the presumption rebutted at step one. ${ }^{177}$

The Court reached a different conclusion with respect to the private cause of action. Importantly, the Court applied the presumption separately to this provision, as opposed to viewing the issue answered by the Court's conclusion on the substantive provisions of RICO. ${ }^{178}$ At step one, the Court concluded "that $§ 1964$ (c) does not overcome the presumption against extraterritoriality," instead requiring that "[a] private RICO plaintiff . . . allege and prove a domestic injury to its business or property." 179 The Court emphasized the risk of "international friction" that could arise by affording extraterritorial reach to the private cause of action. ${ }^{180}$ While the Court in Morrison had eschewed concerns over such conflicts, the Court in RJR

171. Id. at 2101.

172. Holbrook, What Counts?, supra note 51, at 293-94 ("Notably, the step one assessment does not depend on the conduct at issue in the case, meaning that it can have precedential consequences that extend well beyond any particular case.").

173. RJR Nabisco, $136 \mathrm{~S}$. Ct. at 2101

174. Holbrook, What Counts?, supra note 51, at 294.

175. RJR Nabisco, 136 S. Ct. at 2101. But see supra note 164.

176. RJR Nabisco, $136 \mathrm{~S}$. Ct. at 2102

177. Id. at 2103 ("We therefore do not proceed to the "focus' step.").

178. Id. at 2106 ("The same logic requires that we separately apply the presumption against extraterritoriality to RICO's cause of action despite our conclusion that the presumption has been overcome with respect to RICO's substantive prohibitions.").

179. Id.

180. Id. at 2107 ("Allowing recovery for foreign injuries in a civil RICO action, including treble damages, presents the same danger of international friction."). 
Nabisco described the presumption as at its "apex" when these issues were present. ${ }^{181}$ The Court also rejected a case-by-case approach that would depend on whether the relevant sovereign would consent. ${ }^{182}$

Given the procedural posture of the case, the Court did not reach step two's focus analysis because the only pending claims depended on foreign activity. ${ }^{183}$ So, while articulating a two-step process, the Court never performed the analysis at step two. That omission was soon to be addressed, however. ${ }^{184}$

\section{The Supreme Court Applies Step Two in WesternGeco LLC $\mathrm{V}$. ION GEOPHYSICAL CORP.}

The Court turned to step two in a patent damages case, WesternGeco LLC v. ION Geophysical Corp. ${ }^{185}$ The issue of damages arose in the context of 35 U.S.C. $\S 271(\mathrm{f})$, one of the Supreme Court's favorite infringement provisions. ${ }^{186}$ The case arose among the Federal Circuit's trilogy of cases (including WesternGeco) that created a bright-line rule against damages for extraterritorial activities, even in the face of a predicate act of infringement, under the Patent Act's general damages provision, 35 U.S.C. $\$ 284 .^{187}$

Unlike the Federal Circuit, the Court turned to its RJR Nabisco methodology, although it skipped step one. Acknowledging that addressing step one "is usually preferable," the Court exercised its discretion to resolve the case based on step two alone. ${ }^{188}$ The Court bypassed step one to avoid "resolving 'difficult questions' that do not change 'the outcome of the case,' but could have far-reaching effects in future cases." "189 The Court did not want to answer the question of whether the presumption should ever "apply to statutes, such as $\S 284$, that merely provide a general damages remedy for conduct that Congress has declared unlawful," which has implications for "many other statutes besides the Patent Act." 190

Applying the step two focus analysis, the Court concluded that damages were available for the lost foreign sales in the case. ${ }^{191}$ The Court had to determine the focus of $\S 284$, concluding that it is "the infringement."

181. Id. ("[W]here such a risk [of conflict with foreign law] is evident, the need to enforce the presumption is at its apex.").

182. Id. at 2108 ("We reject the notion that we should forgo the presumption against extraterritoriality and instead permit extraterritorial suits based on a case-by-case inquiry that turns on or looks to the consent of the affected sovereign.").

183. Id. at 2111.

184. It appeared the Supreme Court was going to address the presumption in yet another $\S 271$ (f) case, Life Techs. Corp. v. Promega Corp., 137 S. Ct. 734 (2017). The presumption against extraterritoriality was discussed extensively at oral argument, yet the final decision makes no reference to the presumption at all. See Holbrook, Boundaries, supra note 96, at 1758-59.

185. WesternGeco LLC v. ION Geophysical Corp., 138 S. Ct. 2129 (2018).

186. See supra note 141 and accompanying text.

187. See supra notes $137-142$ and accompanying text.

188. WesternGeco, 138 S. Ct. at 2136-37.

189. Id. (quoting Pearson v. Callahan, 555 U.S. 223, 236-37 (2009)).

190. Id.

191. Id. at 2138 .

192. Id. at 2137 . 
however, is vague, merely stating that " $[\mathrm{u}]$ pon finding for the claimant the court shall award the claimant damages adequate to compensate for the infringement." ${ }^{\prime 193}$ It does not define infringement. Instead, $\S 271$ of the Patent Act defines the acts of infringement, and the particular provision at issue was $\S 271(\mathrm{f})(1)$. As such, to assess the focus of the general damage provision, the Court turned to the infringement provision under which liability was found. ${ }^{194}$ The Court viewed the focus of $\S 271(f)$ as the supplying of components from the United States, which are domestic acts, and those were the relevant acts in this case. ${ }^{195}$ The Court rejected the Federal Circuit's strict territorial limits, at least as articulated for $\S 271(\mathrm{f})$.

While subtle, the Court implicitly answered what had been an open question: whether a general remedy provision should be treated independently or as dependent on the liability-creating provision. The Court chose the latter, which is consistent with the provision-slicing that the Court performed in RJR Nabisco. ${ }^{196}$

Even though WesternGeco was decided at step two, it has already provided guidance to courts on how to approach the issue of the relationships between various statutory provisions in the focus analysis. ${ }^{197}$ Thus, its impact is already being felt outside of intellectual property law.

\section{IS THERE A NEW EXTRATERRITORIALITY IN INTELLECTUAL PROPERTY?}

The Supreme Court has worked to clarify the role of the presumption against extraterritoriality, adopting a two-step methodology that is to apply to all statutes and all cases. The Court clarified that the presumption must be assessed for each provision of the same statutory scheme, including an assessment as to remedies even if extraterritoriality is not at issue at the liability stage. The Court resolved lingering ambiguities as to whether the presumption applies to any component of the claimliability, damages, and perhaps jurisdiction - and whether the presumption can apply to different parts of the same statutory regime, answering both in the affirmative.

There are open questions, however. For example, what happens if, at step one, the presumption is rebutted? What role does the presumption continue to have, if any? In Morrison, the Court suggested that a role remains in a manner akin to the

193. 35 U.S.C. $\$ 284$. WesternGeco, 138 S. Ct. at 2137 ("We conclude that 'the infringement' is the focus of this statute.").

194. Id. at 2129 ("To determine the focus of $\S 284$ in a given case, we must look to the type of infringement that occurred. We thus turn to $\S 271(\mathrm{f})(2)$, which was the basis for WesternGeco's infringement claim and the lost-profits damages that it received." (footnote omitted)).

195. Id. at 2138 .

196. See Holbrook, Proximate Cause, supra note 90, at 196 ("Importantly, the Court made clear that the extraterritorial reach of a general remedy provision depends upon the corresponding liability provision.").

197. See In re Picard, Tr. for Liquidation of Bernard L. Madoff Inv. Sec. LLC, 917 F.3d 85, 97 (2d Cir. 2019) ("Just as the focus of $\S 284$ of the Patent Act depends on the infringement provision that enables a plaintiff to seek damages, the focus of $\S 550$ (a) of the Bankruptcy Code depends on the avoidance provision that enables a trustee to recover property."); United States v. Wolfenbarger, No. 16-CR-00519LHK-1, 2020 WL 2614958, at *7 (N.D. Cal. May 22, 2020). 
Court's use of the presumption in Microsoft, though it is unclear. ${ }^{198}$ Relatedly, by skipping step one in WesternGeco, the Court declined to answer the question of the application of the presumption to a general remedial statute. Additionally, conspicuously, and relevant to intellectual property, the Supreme Court did not square its reasoning in Bulova with its newly articulated framework.

In the face of the Court's efforts, it also remains unclear how much the lower courts have internalized these efforts, particularly as they relate to intellectual property law. Given the state of affairs prior to the Court's recent interventions and the immense variety of approaches across the intellectual property regimes, this Part reviews what impact, if any, the tetralogy has had on extraterritoriality doctrine in trademark, copyright, and patent law. ${ }^{199}$

\section{A. Trademark LaW}

Within the Supreme Court's interventions in extraterritoriality is a conspicuous failure to engage with one of its longest-standing extraterritoriality cases, Steele $v$. Bulova. $^{200}$ The Court in Morrison only mentioned Bulova in a footnote, noting that the Court afforded the Lanham Act extraterritorial reach in that case. ${ }^{201}$ The Court never cites or mentions Bulova in Kiobel, RJR Nabisco, or WesternGeco. While the Court seems to believe that Bulova remains good law, the reasoning in Bulova is nowhere close to the methodology of RJR Nabisco. ${ }^{202}$

In particular, the jurisdictional language of Bulova is in tension with Morrison's conclusion that generally extraterritoriality is a question on the merits, not jurisdiction. The viability of Bulova, therefore, is in question, despite the fact that the Supreme Court tends to treat its earlier intellectual property decisions as sacrosanct, even when those cases are irreconcilable with its later holdings and reasonings. ${ }^{203}$

198. Morrison v. Nat'l Austl. Bank Ltd., 561 U.S. 247, 265 (2010) (“Even if that were not true, when a statute provides for some extraterritorial application, the presumption against extraterritoriality operates to limit that provision to its terms." (citing Microsoft Corp. v. AT \& T Corp., 550 U.S. 437, 455-456 (2007)).

199. Although treated as a "before" and "after" the series of Supreme Court cases, there is of course some porousness given that the Supreme Court addressed extraterritoriality over a number of years. I've tried to draw appropriate lines.

200. Steele v. Bulova Watch Co., 344 U.S. 280, 286 (1952).

201. Morrison, 561 U.S. at 272 n.11.

202. But see Dodge, supra note 1, at 1606-07 (viewing Bulova as consistent with the new line of cases).

203. This dynamic can be seen in the Supreme Court's decisions on subject matter eligibility. In Alice Corp. Pty. v. CLS Bank Int'l, 573 U.S. 208 (2014), the Court favorably cites both Parker v. Flook, 437 U.S. 584 (1976) and Diamond v. Diehr, 450 U.S. 175 (1981) when those cases are viewed, at best, in tension with each other, if not completely inconsistent. Alice, 573 U.S. at 222-23 (discussing both cases); see Rebecca S. Eisenberg, Prometheus Rebound: Diagnostics, Nature, and Mathematical Algorithms, 122 YALE L.J. ONLINE 341, 343 (2013) ("Those two cases [Flook and Diehr] reach opposing conclusions on similar facts and are difficult to reconcile."); see also Timothy R. Holbrook \& Mark D. Janis, PatentEligible Processes: An Audience Perspective, 17 VAND. J. ENT. \& TECH. L. 349, 355-57 (2015) (exploring the history and inconsistencies of Flook, Diehr, and other cases). 
Nevertheless, courts have quickly interpreted the Supreme Court's cases in the trademark law context. This Section elaborates on the effect, if any, the Supreme Court has had on trademark law.

\section{Extraterritoriality Is Not a Jurisdictional Question}

The Ninth Circuit was the first to address the impact of the Supreme Court's decisions. In Trader Joe's v. Hallatt, the court squarely addressed whether the issue of extraterritoriality is jurisdictional or part of the merits of a trademark case. ${ }^{204}$ The facts of the case were quite straightforward: "Hallatt purchases Trader Joe's-branded goods in Washington state, transports them to Canada, and resells them there in a store he designed to mimic a Trader Joe's store" called, appropriately enough, "Pirate Joe's." 205 The district court had treated extraterritoriality as jurisdictional, but the Ninth Circuit rejected that approach. Relying on its earlier decision in La Quinta Worldwide LLC v. Q.R.T.M., S.A. de C.V., the court concluded that the issue is one of the merits. ${ }^{206}$ While La Quinta did not face the issue of extraterritoriality, it did address the nature of the Lanham Act's "use in commerce" requirement and held that this too was nonjurisdictional in nature. ${ }^{207}$ Because the Lanham Act's extraterritorial reach is tied to this language, the Ninth Circuit concluded that extraterritoriality is also a merits question. ${ }^{208}$ The Trader Joe's court also viewed this conclusion as consistent with the Supreme Court's decisions in Arbaugh and, importantly, in Morrison. ${ }^{209}$

Other courts are also beginning to recognize that extraterritoriality is not an issue of subject matter jurisdiction under the Lanham Act in light of Morrison. The Tenth Circuit, in a non-precedential decision, also concluded that the issue is one of the merits in Derma Pen, LLC v. 4EverYoung Ltd. ${ }^{210}$ Technically, the question was whether the issue of extraterritoriality had been forfeited. Merits questions can be forfeited, but questions regarding subject matter jurisdiction cannot. ${ }^{211}$ The Tenth Circuit concluded the defendant had forfeited the argument. ${ }^{212}$ District courts in that circuit had reached a similar conclusion. ${ }^{213}$

Although not every circuit court has addressed the issue post-Morrison, those that have considered the matter have concluded that extraterritoriality does not relate to a court's subject matter jurisdiction. This trend seems likely to continue.

\footnotetext{
204. Trader Joe's Co. v. Hallatt, 835 F.3d 960, 966 (9th Cir. 2016).

205. Id. at 962-64.

206. Id. 'at 967.

207. La Quinta Worldwide LLC v. Q.R.T.M., S.A. de C.V., 762 F.3d 867 (9th Cir. 2014).

208. Trader Joe's, 835 F.3d at 967 ("La Quinta's jurisdictional analysis still dictates the outcome here.").

209. Id. at 968 (calling Morrison's reasoning "equally applicable to the Lanham Act").

210. Derma Pen, LLC v. 4EverYoung Ltd., 736 F. App’x 741 (10th Cir. 2018).

211. See, e.g., Huffman v. Saul Holdings Ltd. P'ship, 194 F.3d 1072, 1076-77 (10th Cir. 1999) (“A defect in subject matter jurisdiction can never be waived and may be raised at any time.").

212. Derma Pen, 736 F. App'x at 748 n.4.

213. Hetronic Int'l, Inc. v. Hetronic Germany GmbH, No. CIV-14-650-F, 2020 WL 1941309, at *2 (W.D. Okla. Apr. 22, 2020) (citing Derma Pen, 736 F App'x at 748 n.4); A.O. Smith Corp. v. USA Smith Indus. Dev. Inc., No. 16-CV-2587-WJM-MJW, 2017 WL 2224539, at *2 (D. Colo. May 22, 2017).
} 


\section{The Mixed, Somewhat Odd Application of RJR Nabisco To Trademark Liability Determinations}

The Ninth Circuit was one of the first to apply the Supreme Court's doctrine in terms of liability as well. The Ninth Circuit's approach to the RJR Nabisco two-step framework, though, demonstrates a misapprehension of the two steps. The court concluded at step one that the presumption was rebutted given Bulova. ${ }^{214}$ But then, things went off the rails.

The court characterized step two as requiring courts to "consider "the limits Congress has (or has not) imposed on the statute's foreign application." 215 As a formal matter, that is not step two of the framework, which is instead the focus analysis. What the Ninth Circuit characterized as step two is in fact part of the step one analysis: If the presumption is rebutted, a court is then to consider such structural limits in the statute that could yet limit its extraterritorial reach. ${ }^{216}$ The Supreme Court made clear that this analysis is distinct from the focus analysis of step two. ${ }^{217}$ Because the presumption was rebutted at step one, the Ninth Circuit necessarily did not perform a step two focus analysis. The limits articulated at step one by $R J R$ Nabisco should perhaps be deemed step 1.5.

But the court did make an interesting move. In discussing potential structural limits on the Lanham Act's foreign application, the court simply incorporated its longstanding three-prong Timberlane test for extraterritoriality. ${ }^{218}$ This test assesses (1) whether there is "some effect on American foreign commerce"; (2) whether that effect is "sufficiently great to present a cognizable injury to the plaintiffs under the Lanham Act"; and (3) "whether the interests of and links to American foreign commerce [are] sufficiently strong in relation to those of other nations to justify an assertion of extraterritorial authority," which includes a consideration of international

214. Trader Joe's, 835 F.3d at 966 ("The Supreme Court settled this question with regard to the Lanham Act when it held that the Act's 'use in commerce' element and broad definition of 'commerce' clearly indicate Congress's intent that the Act should apply extraterritorially.") (citing Steele v. Bulova Watch Co., 344 U.S. 280, 286 (1952)).

215. Id. (quoting RJR Nabisco, Inc. v. Eur. Cmty., 136 S. Ct. 2090, 2101 (2016)).

216. See RJR Nabisco, 136 S. Ct. at 2101 ("What if we find at step one that a statute clearly does have extraterritorial effect?... The scope of an extraterritorial statute thus turns on the limits Congress has (or has not) imposed on the statute's foreign application, and not on the statute's 'focus." (emphasis omitted)).

217. Id.

218. Trader Joe's, 835 F.3d at 969 ("Whether this provision sweeps foreign activities into the Act's proscriptive reach depends on a three-part test we originally applied to the Sherman Act in Timberlane Lumber Co. v. Bank of America National Trust \& Savings Ass'n, 549 F.2d 597 (9th Cir. 1976).”). See Comment, Foreign Relations Law — Lanham Act Extraterritoriality—Ninth Circuit Applies Lanham Act to Wholly Foreign Sales.-Trader Joe's Co. v. Hallatt, 835 F.3d 960 (9th Cir. 2016), 130 HARV. L. REv. 1946, 1951 (2017) ("This narrowing of extraterritoriality by the Supreme Court has not, to date, affected... the inquiry into 'the limits Congress has (or has not) imposed on the statute's foreign application.'”). 
comity. ${ }^{219}$ The Ninth Circuit's approach significantly pre-dates the Supreme Court's reengagement with extraterritoriality and is rooted in Bulova. ${ }^{220}$

The Ninth Circuit, applying this analysis, ultimately found Trader Joe's had demonstrated sufficient harm under the first two prongs. It then turned to its comity analysis, which requires a court to consider seven different factors:

[1] the degree of conflict with foreign law or policy, [2] the nationality or allegiance of the parties and the locations or principal places of business of corporations, [3] the extent to which enforcement by either state can be expected to achieve compliance, [4] the relative significance of effects on the United States as compared with those elsewhere,

[5] the extent to which there is explicit purpose to harm or affect American commerce,

[6] the foreseeability of such effect, and [7] the relative importance to the violations charged of conduct within the United States as compared with conduct abroad. ${ }^{221}$

The court concluded that Trader Joe's had demonstrated a superior interest in the United States relative to Canada, such that extraterritorial application of the Lanham Act was appropriate in the case.

Interestingly, the court's formal use of comity is at least facially inconsistent with the Supreme Court's recent line of cases. In Morrison, the Supreme Court explicitly stated that the presence or absence of a conflict is irrelevant to the presumption: "The canon or presumption applies regardless of whether there is a risk of conflict between the American statute and a foreign law."222 The Supreme Court itself has somewhat retreated from that specific language in Morrison, noting that while conflicts are not essential, "where such a risk is evident, the need to enforce the presumption is at its apex." 223 The Supreme Court, therefore, has sent a mixed message as to the role of comity and potential conflicts of law. Trader Joe's is also in a different posture because the Ninth Circuit already concluded the presumption had been rebutted, yet it formally considered the conflicts as a prudential matter.

District courts have begun to interrogate the Trader Joe's approach and, in so doing, generally have ignored RJR Nabisco's two-step framework. Within the Ninth Circuit, for example, the district court in Rousselot B.V. v. St. Paul Brands, Inc., simply followed the three-prong analysis from Trader Joe's, with no reference to the two-step process of RJR Nabisco. ${ }^{224}$ Oddly, the Rousselot court cited RJR Nabisco favorably as embracing a comity analysis, which is far from clear. ${ }^{225}$ The Rousselot court afforded extraterritorial protection in that case. ${ }^{226}$ Other courts have followed the same analysis and allowed cases of an extraterritorial nature to move forward. ${ }^{227}$

219. Trader Joe's, 835 F.3d at 969 (quoting Love v. Associated Newspapers, Ltd., 611 F.3d 601, 613 (9th Cir. 2010)).

220. See, e.g., Star-Kist Foods, Inc. v. P.J. Rhodes \& Co., 769 F.2d 1393, 1395-96 (9th Cir. 1985).

221. Trader Joe's, 835 F.3d at 972-73 (quoting Star-Kist Foods, 769 F.2d at 1395).

222. Morrison v. Nat'l Austl. Bank Ltd., 561 U.S. 247, 255 (2010).

223. RJR Nabisco, Inc. v. Eur. Cmty., 136 S. Ct. 2090, 2107 (2016).

224. Rousselot B.V. v. St. Paul Brands, Inc., No. SA-CV-19-0458-DOC (ADSx), 2019 WL 6825763, at $* 7$ (C.D. Cal. July 24,2019$)$.

225. Id. at $* 5$.

226. $I d$. at *7 (finding all three factors satisfied).

227. See, e.g., BLK Enters., LLC v. Unix Packaging, Inc., No. 2:18-cv-02151-SVW-KS, 2018 WL 5993844, at*7 (C.D. Cal. June 14, 2018); Updateme Inc. v. Axel Springer SE, No. 17-cv-05054-SI, 2018 
In others, such claims are rejected, but the courts still apply the Trader Joe's analysis with, at best, gestures to the Supreme Court line of cases. ${ }^{228}$

Concerningly, other courts have extended the Trader Joe's misstatement about the nature of the two-step analysis in RJR Nabisco. For example, one district court, parroting the language in Trader Joe's, characterized the two-step analysis as follows: "(1) 'whether the statute gives a clear, affirmative indication that it applies extraterritorially' and (2) whether Congress has imposed limits on the statute's foreign application and if so, how those apply." ${ }^{229}$ This statement is simply incorrect. The assessment of any congressionally imposed limits is part of the first step under RJR Nabisco, which assesses whether the presumption has been rebutted. Step two, instead, is the focus analysis. Of course, if the presumption is rebutted at step one, there is no need to consider step two. Nevertheless, the mischaracterization of the steps adds unneeded confusion into the case law.

Other courts outside of the Ninth Circuit have also begun to address the extraterritorial reach of the Lanham Act. The D.C. Circuit recently addressed the RJR Nabisco framework, though it offered an analysis that failed to consider step two at all. In IMAPizza, LLC v. At Pizza Ltd., the D.C. Circuit started with step one, but then pivoted to Bulova, noting that "[i]n Morrison v. National Australia Bank Ltd., the Supreme Court reiterated that its opinion in Steele v. Bulova Watch Co., 'interpret[ed] ... the Lanham Act to have extraterritorial effect,' and so it is to Steele we look to determine whether the Lanham Act applies to particular conduct abroad." 230 The court recognized the myriad circuit court tests for extraterritorial application under the Lanham Act, but ultimately declined to embrace any particular one, reasoning "with no need to commit this Circuit to one standard or another, we hold IMAPizza failed to state a claim under the Lanham Act because it failed to allege some plausible effect-let alone a significant or substantial effect-upon U.S. commerce." ${ }^{231}$ Interestingly, the court engaged in an intensive factual analysis regarding the effects on U.S. commerce in a fashion inconsistent with step one being an act of statutory interpretation. ${ }^{232}$ The court seemingly concluded that the presumption, in light of Bulova, had been rebutted, which was "the end of the matter." 233 Step two would be unnecessary in this context. Yet, the factual inquiry undertaken by the court aligns more with step two, which is never even mentioned in

WL 1184797, at*9 (N.D. Cal. Mar. 7, 2018); Sound N Light Animatronics Co. v. Cloud B, Inc., No. CV 16-05271-BRO (JPR), 2017 WL 3081685, at *11, 13 (C.D. Cal. Apr. 7, 2017).

228. See, e.g., Levy v. Adidas AG, No. CV 18-6542 PSG (MAAx), 2018 WL 5942000, at*4-5 (C.D. Cal. Nov. 13, 2018); Sarieddine v. D\&A Distrib., LLC, No. 2:17-cv-2390-DSF (SKx), 2018 WL 5094937, at *2 (C.D. Cal. Apr. 6, 2018); Asuragen, Inc. v. Accuragen, Inc., No. 16-cv-05440-RS, 2018 WL 558888, at *8 (N.D. Cal. Jan. 25, 2018).

229. BLK Enters., 2018 WL 5993844, at *5 (quoting Trader Joe's Co. v. Hallatt, 835 F.3d 960, 966 (9th Cir. 2016)).

230. IMAPizza, LLC v. At Pizza Ltd., 965 F.3d 871, 879 (D.C. Cir. 2020) (citations omitted).

231. Id. at 881 .

232. Id. at $880-81$ (discussing students and tourists buying food overseas, the confusion of a potential business partner, and the "number and nature of the defendants' visits to the U.S. to research \&pizza restaurants").

233. Id. at 880 (citing RJR Nabisco, Inc. v. Eur. Cmty., 136 S. Ct. 2090, 2101 (2016)). 
the decision. ${ }^{234}$ Minimally, the court's reasoning in IMAPizza shows the ambiguity that remains at step one: What should courts do once the presumption has been deemed rebutted? ? $^{235}$

Where circuit courts have not yet addressed the issue, district courts have begun to address the issue on their own. For example, the Western District of Oklahoma, recognizing that neither the Supreme Court in Bulova nor the Tenth Circuit have articulated a clear test for extraterritoriality, embraced both the Second Circuit's Vanity Fair test ${ }^{236}$ and the Ninth Circuit's Trader Joe's test, ${ }^{237}$ but did so without engaging the RJR Nabisco framework at all. ${ }^{238}$ District courts in the Second Circuit also have addressed the extraterritorial scope of the Lanham Act and, after gesturing to RJR Nabisco, have gone on to apply the Second Circuit precedent from before the Supreme Court's tetralogy of cases. ${ }^{239}$

This review demonstrates the fractured results of the courts' application of $R J R$ Nabisco. The D.C. Circuit's reasoning is particularly suspect and is actually inconsistent with RJR Nabisco. While Bulova remains good law, the court failed to map that decision onto the two-step framework. Indeed, the reasoning of Bulova seems more apt under step two than step one. Step one is a legal analysis of the statutory provisions at issue to assess, as a legal matter, whether the presumption has been rebutted. Step two involves the factual analysis of the focus of the statute. The reasoning in Bulova is fact-intensive, considering the effect on U.S. commerce, the citizenship of the accused infringer, and potential conflicts with foreign law. This looks nothing like a step one inquiry.

One could argue that the courts' sidestepping of the RJR Nabisco framework could be viewed as appropriate in the trademark context. Step one's analysis of whether the presumption has been rebutted is a legal question, and the answer to that question has long been clear since Bulova. So, instead of starting formally at step one, the courts are jumping immediately to the three-step analysis used before RJR Nabisco.

234. As discussed infra Part IV.A, the court also failed to engage with the framework in addressing the copyright issues in the case. See IMAPizza, 965 F.3d at 876, 879.

235. See supra note 198 and accompanying text.

236. The Second Circuit articulated three factors for analyzing extraterritoriality under the Lanham Act: "(1) the defendant's conduct had a substantial effect on United States commerce; (2) the defendant was a United States citizen and the United States has a broad power to regulate the conduct of its citizens in foreign countries; and (3) there was no conflict with trade-mark rights established under the foreign law." Vanity Fair Mills, Inc. v. T. Eaton Co., 234 F.2d 633, 642 (2d Cir. 1956). The court noted that "the absence of one of the above factors might well be determinative and that the absence of both is certainly fatal," id. at 643, affording these factors a more formalistic nature than a classic balancing test. See supra note 42 .

237. See supra notes 218-221 and accompanying text.

238. Hetronic Int'l, Inc. v. Hetronic Ger. GmbH, No. CIV-14-650-F, 2019 WL 3021689, at *4 (W.D. Okla. Mar. 22, 2019) ("The Court, however, has not set forth a specific framework for determining when the extraterritorial application of the Lanham Act is warranted. The Tenth Circuit also has not established a formulation for making that determination, but other circuit courts have."). The only reference in the case to any of the Supreme Court's decisions is to Morrison's conclusion that extraterritoriality is not jurisdictional but instead related to the merits. Id. at $* 4$.

239. See Bruce Kirby, Inc. v. LaserPerformance (Eur.) Ltd., No. 3:13-cv-00297 (JAM), 2018 WL 3614116, at*3-4 (D. Conn. July 27, 2018); Int'’1 Diamond Imps., Inc. v. Med Art, Inc., No. 15-CV-4045 (KMW), 2017 WL 2839640, at *8 (S.D.N.Y. June 29, 2017). 
The three-step test also reflects the fluidity of trademark protection, where consumer awareness of the mark and the associated goodwill can easily flow across national borders. But, even if that move is efficient and appropriate, it remains an open question whether the three-step approach to the presumption actually does survive the Supreme Court's interventions.

\section{B. COpyright LAW}

As with trademark law, the courts are just beginning to explore what impact the Supreme Court's recent extraterritoriality jurisprudence has had on copyright. Also similar to trademark, the courts' approaches have differed, but generally have resulted in the preservation of earlier case law.

\section{Morrison Is Leading Towards Extraterritoriality in Copyright Not Being Jurisdictional}

As in trademark law, Morrison's reasoning provided guidance as to the nature of the extraterritoriality question in copyright law-whether it is jurisdictional or goes to the merits. Although Morrison addressed the Securities and Exchange Act, not copyright, the Supreme Court did hold that extraterritoriality in that context is not jurisdictional.

In Geophysical Service, Inc. v. TGS-NOPEC Geophysical Co., the Fifth Circuit explored this issue, drawing on Morrison to hold that extraterritoriality in copyright law similarly is not jurisdictional. ${ }^{240}$ The Southern District of New York, relying on both Morrison and Geophysical Service, departed from earlier district court decisions to reach the same conclusion in Noland v. Janssen. ${ }^{241}$ However, the district court's earlier, post-Morrison cases treated the question as jurisdictional. ${ }^{242}$ Those decisions, however, never cited to Morrison and never explicitly engaged with the question, simply treating it as settled that the issue is one of subject matter jurisdiction. ${ }^{243}$ Still, the Second Circuit will need to address this divergence among its district courts over the nature of the questions and, post-Morrison, should clarify that the issue is not jurisdictional.

240. Geophysical Serv., Inc. v. TGS-NOPEC Geophysical Co., 850 F.3d 785, 791 (5th Cir. 2017) ("We are persuaded that bounding the reach of the Copyright Act to territorial conduct presents a question of the merits of the claim, not the jurisdiction of the court.").

241. Noland v. Janssen, No. 17-CV-5452 (JPO), 2019 WL 1099805, at*5 n.5 (S.D.N.Y. Mar. 8, 2019).

242. See Hutson v. Notorious B.I.G., LLC, No. 14-cv-2307 (RJS), 2015 WL 9450623, at *6 (S.D.N.Y. Dec. 22, 2015); Levitin v. Sony Music En’t., 101 F. Supp. 3d 376, 384 (S.D.N.Y. 2015).

243. See Hutson, 2015 WL 9450623, at *6 (citing Levitin and other cases with no discussion); Levitin, 101 F. Supp. 3d at 384 (stating "district courts do not have subject matter jurisdiction over infringement occurring outside of the United States" and citing pre-Morrison Second Circuit precedent). 


\section{Courts' Engagement with the Supreme Court's Recent Case Law Is Mixed}

In addition to the nature of the issue of extraterritoriality, circuit courts and district courts have begun to consider the impact of the Supreme Court's recent jurisprudence in assessing copyright infringement liability. As with trademark law, the results have been mixed, at best.

The D.C. Circuit has used the RJR Nabisco framework to assess the extraterritorial reach of the Copyright Act. In Spanski Enterprises, Inc. v. Telewizja Polska, S.A., the performance of the copyrighted shows at issue had originated in Poland but reached viewers in the United States. ${ }^{244}$ At step one of the RJR Nabisco methodology, relying on the traditional territorial limits of copyright, the court summarily concluded that the presumption against extraterritoriality had not been rebutted. ${ }^{245}$ As to step two's focus analysis, the court looked to the relevant acts of infringement, particularly the exclusive right to perform the copyrighted work publicly. ${ }^{246}$ The court reasoned that "although it was in Poland that TV Polska uploaded and digitally formatted the fifty-one episodes, the infringing performances - and consequent violation of Spanski's copyrights - occurred on the computer screens in the United States on which the episodes' 'images' were 'show[n]."' 247 Because those acts fell within the focus of the statute, the court concluded there was infringement of the U.S. copyright, effectively affording some protection to the copyright holder over activity originating overseas. ${ }^{248}$

The D.C. Circuit subsequently built on its holding in Spanski in IMAPizza, LLC v. At Pizza Ltd. ${ }^{249}$ The accused infringer was in the United Kingdom, so the court focused its analysis of the locus of infringement on two acts: (1) downloading the plaintiff's copyrighted pictures of the plaintiff's restaurants from websites operating on servers in the U.S., and (2) taking pictures of the restaurants in the United States. The court drew on the focus analysis in Spanski to conclude that there was no infringement. As to the pictures downloaded from U.S. servers, the court concluded that the act of copying took place in the U.K. because that is where the image became fixed. ${ }^{250}$

"[E]phemeral transmission of a picture across the internet" does not constitute copying. ${ }^{251}$ The court distinguished Spanski because the act of infringement therea public performance - did take place within the U.S. As to the photos taken in IMAPizza, "the Copyright Act does not create a right to prevent the taking of pictures

\footnotetext{
244. Spanski Enters., Inc. v. Telewizja Polska, S.A, 883 F.3d 904, 913 (D.C. Cir. 2018).

245. Id.

246. Id. at 914 .

247. Id. (quoting 17 U.S.C. $§ 101$ ).

248. Id. at 917 .

249. IMAPizza, LLC v. At Pizza Ltd., 965 F.3d 871, 876-77 (D.C. Cir. 2020). The case also has a trademark component, discussed infra Part IV.A.

250. Id. at 877 .

251. Id.
} 
of an architectural work 'if the building in which the work is embodied is located in or ordinarily visible from a public place.",252

These two cases offer insights into the court's engagement with the RJR Nabisco framework. The Spanski holding, while technically fact-specific, creates a fairly broad swath of extraterritorial protection for U.S. copyright owners. If a work is placed on the internet and is accessible in the U.S., the copyright holder will be able to sue for infringement in the United States, even if the immediate act of infringement occurred in a foreign country. IMAPizza shows the converse: Downloading images abroad will not constitute infringement. ${ }^{253}$ When coupled with the predicate act doctrine for damages, the Spanski holding affords considerable reach to U.S. copyright law. ${ }^{254}$

This approach contrasts, however, with two district court cases decided after Morrison. Confronting fact patterns similar to Spanski, these district courts reached the same conclusion as the D.C. Circuit, though with different reasoning.

In Shropshire v. Canning, the Northern District of California addressed whether "uploading a video from Canada to YouTube's servers in California for display within the United States" constituted an act of infringement. ${ }^{255}$ In rejecting the motion to dismiss, the court concluded that, while the video was created in Canada, uploading it to YouTube servers created a copy and led to viewings by "potentially thousands in the United States," which are acts of infringement in the United States. ${ }^{256}$ The case, however, never discussed Morrison. To be fair to the court, of the tetralogy, only Morrison had been decided, so the Supreme Court had not yet laid out its two-step RJR Nabisco framework.

The same cannot be said for Sound N Light Animatronics Co. v. Cloud B, Inc., which was decided after RJR Nabisco, although before WesternGeco. ${ }^{257}$ Indeed, the decision by the Central District of California starts promisingly with a lengthy discussion of the RJR Nabisco framework. ${ }^{258}$ Yet, when the court turns to the copyright issue in the case, the two-step framework vanishes. The court instead drew upon pre-Morrison copyright cases, such as SubaFilms. ${ }^{259}$ The court also relied heavily on Shropshire to permit the claim to go forward because the accused infringer "actively targets potential consumers in the United States with Cloud-b's

252. Id. at 878 (quoting 17 U.S.C. $§ 120($ a)). The court also rejected the plaintiff's attempt to create a quasi-predicate act doctrine as a form of liability as opposed to a damages measure. See id.

253. The copyright owner suggested that the holding would allow widespread global infringement of anything on U.S. servers. The court did note, though, that uploading a copyrighted work without permission would constitute infringement, creating some protection against this potential. Id. at 879 ("The unauthorized upload of a video to a server in the U.S. for unauthorized distribution abroad would be an act of infringement in the U.S.").

254. See Kyle A. Mason, The "Presumption Against Extra(subjective)territoriality": Morrison's Confounding "Focus" Test, 38 REV. LiTIG. 385, 401 n.123 (2019) (criticizing the malleability of the "focus" test in Spanksi).

255. Shropshire v. Canning, 809 F. Supp. 2d 1139, 1145 (N.D. Cal. 2011)

256. Id. at 1146.

257. Sound N Light Animatronics Co. v. Cloud B, Inc., No. CV 16-05271-BRO (JPR), 2017 WL 3081685, at*3 (C.D. Cal. Apr. 7, 2017).

258. Id. at *3-4.

259. Id. at $* 6$. 
products." 260 Yet, notwithstanding the recitation of the RJR Nabisco framework, the court never discussed it in the copyright context.

Other district courts have failed to fully account for the Supreme Court's intervention as well, instead relying on earlier circuit court case law. ${ }^{261}$ The impact of the Supreme Court's recent extraterritoriality jurisprudence therefore has been mixed, at best, in the copyright liability context. Some courts have turned to the framework, particularly step two, in analyzing the focus of the statute, although subsequent courts have failed to do so. Other district courts have simply failed to engage the framework, if they even cite the cases at all. If the Supreme Court's goal was to harmonize the law of extraterritoriality across subject matters, it is failing in the copyright context. ${ }^{262}$

\section{The Predicate Act Doctrine Survives the Supreme Court's Tetralogy}

The predicate act doctrine allows the award of damages for acts outside of the United States so long as there is a domestic predicate act of infringement. That scenario is quite similar to the situation in WesternGeco, where the domestic act of supplying the patented component justified the award of damages for foreign activities. WesternGeco was an application of the focus analysis of step two. The predicate act doctrine therefore would seem ripe for reconsideration in light of the Supreme Court's recent cases. The courts have made clear that the doctrine has survived but have conspicuously not used the two-step framework in reaching that conclusion.

The first circuit court to consider the predicate act doctrine after Morrison was the Fourth Circuit. In Tire Engineering \& Distribution, LLC v. Shandong Linglong Rubber Co., the court joined other circuits in adopting the predicate act doctrine. ${ }^{263}$ In making that move, the court addressed other copyright extraterritoriality cases, but conspicuously, it never even cites-let alone discusses-Morrison. ${ }^{264}$ The Fourth Circuit only had the benefit of Morrison and not the subsequent Supreme Court decisions. $^{265}$ Yet, other courts applying the predicate act doctrine similarly have failed to account for the presumption even in the face of these later decisions. ${ }^{266}$

260. Id. at *6-7.

261. See, e.g., Goes Int'l, AB v. Dodur Ltd., No. 14-cv-05666-LB, 2016 WL 427369, at *3 (N.D. Cal. Feb. 4, 2016); Crunchyroll, Inc. v. Pledge, No. C 11-2334 SBA, 2014 WL 1347492, at*17 (N.D. Cal. Mar. 31, 2014).

262. Cf. Holbrook, Supreme Court's Interest, supra note 131, at 71-72 (discussing the Supreme Court's interest in aligning patent law extraterritoriality with other areas of the law).

263. 682 F.3d 292, 308 (4th Cir. 2012) ("We join our sister circuits that have adopted the predicateact doctrine.")."

264. Id. at 306-08.

265. See also Minden Pictures, Inc. v. Pearson Educ., No. C 11-05385 WHA., 2013 WL 71774, at *1-2 (N.D. Cal. Jan. 7, 2013) (discussing predicate act doctrine without reference to Morrison); In re Outsidewall Tire Litig., No. 1:09cv1217. 2010 WL 11474982, at *6-7 (E.D. Va. Sept. 17, 2010) (same).

266. See, e.g., Noland v. Janssen, 17-CV-5452 (JPO), 2020 WL 2836464, at*3 (S.D.N.Y. 2020) (failing to discuss any of the tetralogy); Fair Isaac Corp. v. Fed. Ins. Co., 447 F. Supp. 3d 857, 892-93 (D. Minn. 2020) (same); Int'l Diamond Imps., Inc. v. Med Art, Inc., No. 15-CV-4045 (KMW), 2017 WL 2839640, at *8-9 (S.D.N.Y. June 29, 2017) (failing to discuss the Morrsion, Kiobel, or RJR Nabisco 
One court did recognize that the Supreme Court's recent decisions implicated the predicate act doctrine. The district court in Motorola Solutions, Inc. v. Hytera Communications recognized that the Supreme Court's alteration of its extraterritoriality jurisprudence could have an impact on the predicate act doctrine. ${ }^{267}$ But after recognizing this possibility, the court summarily concluded that there was no impact on the predicate act doctrine, after all:

Although Defendants argue that modem [sic, modern] extraterritorial jurisprudence displaces the predicate-act doctrine, the Court disagrees, and the predicate-act doctrine holds similarities to the Supreme Court's recent analysis in WesternGeco. ${ }^{268}$

This lack of analysis is surprising on a number of levels. Earlier in the opinion, the court performed a robust analysis of the extraterritorial reach of the Defend Trade Secrets Act, engaging extensively with the Supreme Court's recent decisions, so the court was familiar with the two-step methodology. ${ }^{269}$ Moreover, although the court lamented that "[t]he parties have provided considerably less argument with respect to damages under the Copyright Act," the defendant did argue that the predicate act doctrine should be revisited. ${ }^{270}$ The court could have moved quickly past step one, given the consistent refrain that the Copyright Act does not extend extraterritoriality.

The Motorola court's intuitions about the appropriate outcome in the case may very well be correct. It was not a far stretch, given the similarities between the facts of WesternGeco and that case, to allow the award of damages. Unfortunately, the court simply jumped to that conclusion rather than performing the contextual analysis of the focus of the relevant infringement provisions in relation to the facts in the case, as the court had done in WesternGeco. Because the focus analysis does generally depend on the facts of the case, the court should have interrogated both whether the predicate act doctrine survives Morrison and its progeny generally, and if so, whether the facts of the case fell within the focus of the statute to justify damages. The court provided no such analysis. In neglecting to do so, the court short-circuited a complete analysis, which would have assisted other courts in more fully understanding the appropriate analysis of step two. The court's opinion reflects a significant missed opportunity.

Courts' analyses of how the new framework for presumption impacts copyright law have been mixed, at best. The new framework does call into question the prior copyright case law. On an issue of first impression, the D.C. Circuit did turn to the presumption. In other areas, however, the courts simply ignored the presumption,

\footnotetext{
decisions); Perfect 10, Inc. v. Yandex N.V., 962 F. Supp. 2d 1146, 1158 (N.D. Cal. 2013), as amended (Sept. 6, 2013) (discussing predicate act doctrine with no reference to Morrison or Kiobel).

267. 436 F. Supp. 3d. 1150, 1166 (N.D. Ill. 2020) (citing WesternGeco LLC v. ION Geophysical Corp., 138 S. Ct. 2129, 2137 (2018)).

268. Id.

269. Id. at $1155-67$.

270. Id. at 1167 .
} 
drawing on the pre-Morrison case law without a second thought. If the Supreme Court hoped to harmonize extraterritoriality jurisprudence across different areas of the law, it has failed in the copyright context.

\section{Patent Law}

The impact of the Supreme Court's interventions remains to be seen at the Federal Circuit. As to the jurisdictional question remaining in trademark and copyright, the Supreme Court has provided no reason for the Federal Circuit to revisit its holding that extraterritoriality is a question of the merits, not subject matter jurisdiction.

Beyond that simple question, it is clear that the Federal Circuit's engagement with the presumption has been wrong. On the liability side, the Federal Circuit has at times merely gestured to the presumption in interpreting a relevant statute. ${ }^{271}$ In other contexts, the court has relied on a strong view of the presumption to limit the scope of patents or damages. Both approaches are flawed in light of the Supreme Court's modern jurisprudence. The Federal Circuit did draw on the focus analysis articulated in Morrison, so some judges have been attempting to adhere to the Supreme Court's views, though that case was decided prior to RJR Nabisco. Nevertheless, the Federal Circuit, at least in one case addressing extraterritorial damages, simply ignored the Supreme Court's entire string of cases on extraterritoriality. ${ }^{272}$

District courts, however, have begun to wrestle with the impact of the tetralogy, though seemingly with little impact. One district court rejected a motion to dismiss a claim for infringement based on foreign offers to sell the invention within the United States, applying the Transocean rule without any consideration of the new Supreme Court cases. ${ }^{273}$

In terms of damages, district courts have begun to explore the consequences of WesternGeco. In fact, one of the members of the Federal Circuit's trilogy of cases was Power Integration I. ${ }^{274}$ The case was still active after the WesternGeco decision,

271. See, e.g., Merial Ltd. v. Cipla Ltd., 681 F.3d 1283, 1302 (Fed. Cir. 2012) (“Although we recognize the fundamental territoriality of U.S. patent law, Cipla's alleged foreign conduct is not necessarily outside the scope of $\S 271$." (citing Microsoft Corp. v. AT \& T Corp., 550 U.S. 437 (2007))); Transocean Offshore Deepwater Drilling, Inc. v. Maersk Contractors USA, Inc., 617 F.3d 1296, 1309 (Fed. Cir. 2010) (stating that "[w]e are mindful of the presumption against extraterritoriality," yet applying U.S. law to acts external to United States); NTP, Inc. v. Rsch. In Motion, Ltd., 418 F.3d 1282, 1315 (Fed. Cir. 2005) (distinguishing Deepsouth because "this case involves a system that is partly within and partly outside the United States and relates to acts that may be occurring within or outside the United States").

272. See Tex. Advanced Optoelectronic Sols., Inc. v. Renesas Elecs. Am., Inc., 895 F.3d 1304, 1330 (Fed. Cir. 2018) (not citing to any of the Supreme Court cases, notwithstanding discussion of extraterritorial damages), cert. denied, 139 S. Ct. 2741 (2019).

273. Sound N Light Animatronics Co. v. Cloud B, Inc., No. CV 16-05271-BRO (JPR), 2017 WL 3081685, at*8 (C.D. Cal. Apr. 7, 2017) (“Cloud-b's FACC highlights Dongguan's statements that, if true, show that Dongguan offers its products for sale within the United States. These allegations suffice to implicate 35 U.S.C. § 271(a) because Cloud-b is alleging that Counter-Defendants offered infringing products for sale to United States consumers, in United States currency, to be delivered to consumers in the United states.").

274. Carnegie Mellon Univ. v. Marvell Tech. Grp., Ltd., 807 F.3d 1283, 1305-11 (Fed. Cir. 2015); Power Integrations, Inc. v. Fairchild Semiconductor Int'l, Inc., 711 F.3d 1348, 1370-72 (Fed. Cir. 2013) (Power Integrations I). 
leading the court in the District of Delaware to assess whether WesternGeco effectively overruled the Federal Circuit's holding that limited lost profits for forgone sales within the United States only. ${ }^{275}$ The district court held that WesternGeco did overrule the Federal Circuit's earlier decision and was thus inclined to allow damages for lost foreign profits, although its reasoning was thin. The court concluded:

The Supreme Court's analysis of the patent damages statute, $\S 284$, has equal applicability to the direct infringement allegations pending here, as governed by $\S 271(\mathrm{a})$, as it did to the supplying a component infringement claims at issue in WesternGeco II, which were governed by $\S 271(\mathrm{f})(2)$. Fairchild has identified no persuasive reason to conclude that the interpretation of $\S 284$ should differ here from what was available in Western Geco II just because the type of infringing conduct alleged is different. ${ }^{276}$

The court, however, certified the case to the Federal Circuit, which agreed to hear the appeal because the answer to the territoriality question was controlling. ${ }^{277}$ It thus appeared that the continued viability of Power Integrations $I$ would be quickly resolved. Although briefing was complete, the case settled, leaving the impact of WesternGeco on damages under $\S 271$ (a) unanswered by the Federal Circuit.

District courts continue to engage this question. Indeed, two additional district courts have agreed with the district court in Power Integrations II that WesternGeco overruled the territorial limits on $\S 271$ (a) articulated in Power Integrations I and Carnegie Mellon. ${ }^{278}$ In the Eastern District of Texas, the court agreed that damages for foreign activity could be available under $\S 271$ (a) based on the focus of the statute, but it offered a more nuanced analysis than that of the District of Delaware. ${ }^{279}$ The Texas court recognized that the Supreme Court seemed to agree with the Federal Circuit's basic rule that patent owners cannot recover damages for lost foreign sales. ${ }^{280}$ The court, however, distinguished sales of purely foreign origin from those that may have a domestic nexus, thus being made available under step two's focus analysis: "Indeed, setting aside questions of extraterritoriality, under the plain language of the statute, a patent owner cannot recover for purely foreign sales under $\S 271(\mathrm{a})$ because purely foreign sales are not acts of 'infringement' under $\S 271(\mathrm{a}) .{ }^{.281}$

However, WesternGeco does suggest that foreign damages are compensable for domestic infringement under $\S 271(a)$, just as they are compensable for domestic

275. Power Integrations, Inc. v. Fairchild Semiconductor Int'l, Inc., No. CV 04-1371-LPS, 2018 WL 4804685, at *1 (D. Del. Oct. 4, 2018) (Power Integrations II) ("In the Court's view, the Supreme Court's WesternGeco II decision implicitly overruled the Federal Circuit's Power Integrations opinion.").

276. Id.

277. Power Integrations, Inc. v. Fairchild Semiconductor Int'l, No. 19-102, (Fed. Cir. Dec. 3, 2018).

278. Plastronics Socket Partners, Ltd. v. Dong Weon Hwang, No. 218CV00014JRGRSP, 2019 WL 4392525 (E.D. Tex. June 11, 2019); SIMO Holdings Inc. v. H.K. uCloudlink Network Tech. Ltd., 396 F. Supp. 3d 323 (S.D.N.Y. 2019).

279. Plastronics Socket Partners, 2019 WL 4392525, at *5, report and recommendation adopted, No. 2:18-CV-00014-JRG-RSP, 2019 WL 2865079 (E.D. Tex. July 3, 2019) (quoting WesternGeco, 138 S. Ct. at 2135).

280. Id.

281. Id. 
infringement under $\S 271(f)(2)$. For example, a plaintiff might prove that a product made in the United States was sold abroad, that a domestic sale to a regular customer of plaintiff supplanted foreign sales that plaintiff would have made to that customer, or that a product imported into the United States was subsequently sold internationally. Each of these instances would constitute infringement under $\S 271(\mathrm{a})$, and thus, under the reasoning of WesternGeco, would be compensable even if the sale causing damage ultimately occurred abroad. However, a plaintiff cannot recover under $\S 271$ (a) for purely foreign manufacturing, use, sales, or offers because these acts do not constitute infringement under $\$ 271(\mathrm{a}){ }^{282}$

The Texas court therefore adopted an approach to patent infringement damages similar to the predicate act doctrine of copyright law: If there is a domestic predicate act of infringement, then damages for foreign sales may be available. In this way, the court treated the focus analysis in a manner akin to the predicate act doctrine seen previously in patent law.

The Southern District of New York also afforded the patentee damages for foreign activities arising from infringement under $\S 271$ (a). The court similarly distinguished the legal injury of infringement under $\S 271(\mathrm{a})$, which must occur within the United States, from the damages that flow from that injury: "WesternGeco did not hold that a patentee could recover based on acts of infringement committed abroad; it held that you could recover for harms abroad that are proximately caused by domestic acts of infringement."283 Thus, three cases to consider the issue of WesternGeco's impact on Power Integrations I and Carnegie Mellon view both as no longer being good law. A fourth case also appeared to agree with this conclusion, although it ultimately rejected foreign damages on causation grounds. ${ }^{284}$ No case has addressed step one of the RJR Nabisco framework; rather, they have all relied on the focus analysis of step two. Necessarily, the availability of damages in those cases would depend on the facts of the cases - whether the foreign acts were deemed as flowing from an act of domestic infringement.

But the district courts are not entirely in agreement on this issue. Judge Illston in the Northern District of California expressly rejected Judge Sterk's conclusion in Power Integrations II that WesternGeco implicitly overruled the Federal Circuit's decision in Power Integrations I, reasoning:

282. Id.

283. SIMO Holdings Inc. v. H.K. uCloudlink Network Tech. Ltd., 396 F. Supp. 3d 323, 351 (S.D.N.Y. 2019), modified in part on other grounds, No. 18-CV-5427 (JSR), 2019 WL 7816487 (S.D.N.Y. Dec. 11, 2019), clarified on denial of reconsideration, No. 18-CV-5427 (JSR), 2020 WL 498200 (S.D.N.Y. Jan. 22, 2020). Such approaches may suggest a need to reconsider, and perhaps reinvigorate, proximate cause as a limit on damages. See Holbrook, Proximate Cause, supra note 90 at 221-25; see also Dmitry Karshtedt, Causal Responsibility and Patent Infringement, 70 VAND. L. REV. 565, 600 (2017); Stephen Yelderman, Proximate vs. Geographic Limits on Patent Damages, 7 IP THEORY 1, 1-2 (2018).

284. Verinata Health, Inc. v. Ariosa Diagnostics, Inc., 329 F. Supp. 3d 1070, 1106-07 (N.D. Cal. 2018) ("The Court finds Malackowski's argument persuasive and holds that the focus inquiry is satisfied. Nevertheless, precedent dictates that there must be a causal nexus between the lost profits and the infringement. ... Illumina has the burden to prove it would have received profits in foreign countries but for Ariosa's infringement, which it did not do."), order clarified, No. 12-CV-05501-SI, 2018 WL 4849681 (N.D. Cal. Oct. 4, 2018). 
The Court concludes that under Power Integrations I and the cases cited therein, MLC may not seek damages based on Micron's wholly foreign sales. The Court also finds it significant that the Supreme Court denied certiorari in Power Integrations I. Whether Judge Stark is correct that WesternGeco II implicitly overruled Power Integrations I remains to be seen, but at this time controlling law holds that MLC may not seek damages under § 271(a) based on Micron’s wholly foreign sales. ${ }^{285}$

The court, though, simply viewed Power Integrations I as controlling and did not perform its own assessment of the requested damages under the RJR Nabisco framework.

At present, there is a split on this issue between two well-respected patent district courts (District of Delaware and Northern District of California) and two wellrespected patent judges (Judge Sterk and Judge Illston). The matter will need to be resolved by the Federal Circuit and, potentially, the Supreme Court. ${ }^{286}$

All of this analysis confirms that, within patent law, there will need to be a reconsideration of the Federal Circuit's approach to extraterritoriality going forward. A review of its earlier case law shows how those decisions would be different methodologically and could result in different outcomes. Starting with infringement under $\S 271$ (a), step one of the RJR Nabisco framework is fairly straightforward: There is nothing in the statute to rebut the presumption that such a provision does not apply to acts outside of the United States. The statute is specific: the various acts must be "within the United States" or the invention must be imported "into the United States." 287 As step one is a question of statutory interpretation, it is clear here that there is no extraterritorial reach.

But the analysis must move to step two's consideration of the focus of the statute. The focus here would be the various acts of infringement within the United States: making, using, selling, offering to sell, or importing the patented invention. The question becomes, relative to the facts of a given case, what the focus of the statute is. Effectively, the focus analysis appears to mimic the inquiry to the locus of the ultimate action, even if some acts were outside of the United States. ${ }^{288}$ Thus the answer of where the act arises turns on how courts will view what constitutes the various infringing acts.

The NTP case provides a clean example. At issue was the use of a patented system and method where part of the accused device was in Canada. ${ }^{289}$ For the claims to the system, the court was, in essence, determining where the system was used, and it made that assessment by determining the location where control was exercised and

285. MLC Intell. Prop., LLC v. Micron Tech., Inc., No. 14-CV-03657-SI, 2019 WL 2437073, at *3 (N.D. Cal. June 11, 2019) (citations omitted).

286. For the argument that WesternGeco did not overrule Power Integrations, see Holbrook, Proximate Cause, supra note 90, at 209-21 (arguing that foreign damages under 35 U.S.C. § 271(a) should be precluded after WesternGeco); see also Holbrook, Boundaries, supra note 96, at 1777-79 (arguing preWesternGeco that foreign damages should be precluded under $\S 271$ (a) based on RJR Nabisco methodology).

287. 35 U.S.C. $\$ 271(a)$.

288. Mark A. Lemley, David O’Brien, Ryan M. Kent, Ashok Ramani, Robert Van Nest, Divided Infringement Claims, 33 AIPLA Q.J. 255, 269 (2005).

289. NTP, Inc. v. Rsch. In Motion, Ltd., 418 F.3d 1282, 1317 (Fed. Cir. 2005). 
to where the beneficial use flowed. ${ }^{290}$ This analysis is effectively the focus analysis of step two of RJR Nabisco. The focus of $\S 271$ (a) is the use of the system within the United States, and the primary use of that system was in the United States, even though part of the system lay outside of the United States. ${ }^{291}$ The analysis, therefore, is consonant with RJR Nabisco, even if framed differently than an analysis of the focus of the statute.

That is true for the system claims. But the Federal Circuit's absolutist approach to the infringement of the claimed methods does not withstand scrutiny under the $R J R$ Nabisco framework. The analysis would be the same for both systems claims and method claims by asking: What is the focus of the infringement provision? The use of the method must be within the United States, just as the use of the system must be in the United States, which should yield the same outcome. There is no textual basis for distinguishing patented systems and methods. ${ }^{292}$ Of course, claims to apparatuses and methods are different. ${ }^{293}$ As the NTP court reasoned, because performance of the method requires each step to be performed, all such steps must be within the United States, unlike the use of the system. ${ }^{294}$ But that is a conclusion in search of a justification. One could equally argue that the implementation of the system must also all be within the United States. The focus analysis, though, would focus on the statutory purpose: protecting patentees from infringing uses of the method within the United States, which means the reasoning of "use" would be the same. The NTP court's reasoning as to methods is inconsistent with step two's focus analysis.

Similarly, the focus analysis suggests that the Federal Circuit's approach to infringing offers to sell the patented invention is wrong. In Transocean, the court concluded that the location of the contemplated sale governs the location of the offer to sell the invention. ${ }^{295}$ Because infringement can arise under this provision even if the sale is never consummated, the result is that there could be infringement of a U.S. patent even when no activity takes place within the United States. ${ }^{296}$ Conversely, as highlighted in Halo Electronics v. Pulse Electronics, there is no infringement if acts

290. Id.

291. Cf. RJR Nabisco, Inc. v. Eur. Cmty., 136 S. Ct. 2090, 2101 (2016) ("If the conduct relevant to the statute's focus occurred in the United States, then the case involves a permissible domestic application even if other conduct occurred abroad."); Morrison v. Nat'l Austl. Bank Ltd., 561 U.S. 247, 266 (2010) ("Applying the same mode of analysis here, we think that the focus of the Exchange Act is not upon the place where the deception originated, but upon purchases and sales of securities in the United States.").

292. See Holbrook, Method Patent, supra note 92, at 1044.

293. In re Kollar, 286 F.3d 1326, 1332 (Fed. Cir. 2002) ("The Board also erred in failing to recognize the distinction between a claim to a product, device, or apparatus, all of which are tangible items, and a claim to a process, which consists of a series of acts or steps.").

294. NTP, 418 F.3d at 1318 ("Because a process is nothing more than the sequence of actions of which it is comprised, the use of a process necessarily involves doing or performing each of the steps recited. This is unlike use of a system as a whole, in which the components are used collectively, not individually. We therefore hold that a process cannot be used 'within' the United States as required by section 271(a) unless each of the steps is performed within this country.").

295. Transocean Offshore Deepwater Drilling, Inc. v. Maersk Contractors USA, Inc., 617 F.3d 1296, 1309 (Fed. Cir. 2010) ("The focus should not be on the location of the offer, but rather the location of the future sale that would occur pursuant to the offer.").

296. See Holbrook, Tangibility, supra note 118, at 1111-12. 
of negotiation take place within the United States to sell the invention outside of the United States. ${ }^{297}$

The focus analysis, though, would look at the activity that is meant to be covered by $\S 271$ (a), which is commercial appropriation of the invention within the United States. To that end, it seems likely that the Halo test is correct, requiring the contemplated sale be within the United States. Morrison suggests such an outcome. The analysis in Morrison is particularly illuminating. In Morrison, acts of deception relevant to the securities fraud took place within the United States, even though the sales at issue took place in Australia. ${ }^{298}$ In assessing the focus of the statute, the Court reasoned that "the focus of the Exchange Act is not upon the place where the deception originated, but upon purchases and sales of securities in the United States." ${ }^{299}$ The Court explained that $\S 10$ (b) does not protect against fraud alone but only fraud in conjunction with the sale of qualifying securities, i.e., "transactions in securities listed on domestic exchanges, and domestic transactions in other securities." 300

This reasoning seems directly applicable to the Halo scenario, where there are domestic acts of negotiation but the contemplated sale is outside of the United States. The regulation of such foreign markets is generally deemed outside the scope of a U.S. patent in a way analogous to Morrison. Morrison strongly suggests that the Halo rule is correct.

Even though the Halo rule evolved from the Transocean rule, the latter could be viewed as distinct. In other words, it is possible (and probable) that, under a focus analysis, both the offer and the sale must be within the United States. The Solicitor General has suggested this outcome is the correct approach. ${ }^{301}$ In Texas Advanced Optoelectronic Solutions, Inc. v. Renesas Electronics America, Inc., the Federal Circuit assessed whether extraterritorial damages were available for infringing offers to sell the patented invention. ${ }^{302}$ Applying Halo and Carnegie Mellon (but making no reference to the Supreme Court cases), the court rejected this effort, ultimately eliminating $98.8 \%$ of the asserted damages. ${ }^{303}$

The patentee filed a petition for a writ of certiorari, and the Supreme Court requested the views of the Solicitor General. Ultimately, the Solicitor General recommended against the grant of review because the case was a poor vehicle to address the Transocean/Halo rule, ${ }^{304}$ though the Solicitor General did argue that

297. Halo Elecs., Inc. v. Pulse Elecs., Inc., 831 F.3d 1369, 1378 (Fed. Cir. 2016); see Holbrook, Tangibility, supra note 118, at 1112 .

298. Morrison v. Nat'l Austl. Bank Ltd., 561 U.S. 247, 266 (2010).

299. Id.

300. Id. at 267 .

301. Brief for the United States as Amicus Curiae, Tex. Advanced Optoelectronic Sols., Inc. v. Renesas Elecs. Am., Inc., 139 S. Ct. 2741 (2019) (No. 18-600), 2019 WL 2209264 at*17-18.

302. Tex. Advanced Optoelectronic Sols., Inc. v. Renesas Elecs. Am., Inc., 895 F.3d 1304, 1330 (Fed. Cir. 2018), cert. denied, 139 S. Ct. 2741 (2019).

303. Id. at $1329-31$.

304. Brief for the United States as Amicus Curiae, Tex. Advanced Optoelectronic Sol., Inc. v. Renesas Elecs. Am., Inc., 139 S. Ct. 2741 (2019) (No. 18-600), 2019 WL 2209264, at*17. 
Transocean was wrongly decided. ${ }^{305}$ According to the Solicitor General, both the offer and the contemplated sale should be within the United States for there to be infringement. ${ }^{306}$ The Supreme Court ultimately declined to take the case. ${ }^{307}$

Although the brief did discuss the presumption against extraterritoriality, citing Microsoft v. $A T \& T$ extensively, Deepsouth twice, and WesternGeco only once, ${ }^{308}$ it never cited-let alone applied—Morrison, Kiobel, or RJR Nabisco. ${ }^{309}$ There is no discussion of RJR Nabisco's two-step methodology. Seemingly, the U.S. government has not fully internalized the Supreme Court's efforts to formalize extraterritoriality analyses. ${ }^{310}$ But the analysis, even if inadvertently, does align with a proper focus analysis.

Turning to induced infringement under 35 U.S.C. $\S 271(\mathrm{~b})$, the issue is a bit trickier. The analysis at step one of whether the presumption has been rebutted is more complicated. The statute is silent as to its territorial reach, which means there is not a clear answer as there was to $\S 271(\mathrm{a})$. The amendment to the related contributory infringement provision under $\S 271(\mathrm{c})^{311}$ to add territorial limits implicitly suggests that Congress intends $\S 271$ (b) to have extraterritorial reach, though the failure to amend $\S 271$ (b) could have been inadvertent. ${ }^{312}$ The Federal Circuit used the absence of territorial limits to afford such reach. ${ }^{313}$ Because an act of direct infringement is required for induced infringement, the territorial limits on direct infringement would partially constrain the scope of induced infringement. The answer at step one is thus ambiguous, though the Court's attempt to strengthen the presumption in the face of ambiguity would likely lead the Court to conclude that acts of inducement must be domestic. ${ }^{314}$

At the focus analysis of step two, much would depend on the facts of the case. The focus of $\S 271(\mathrm{~b})$ is the inducement of acts of direct infringement, which generally are those defined in $\S 271(a)$. But $\S 271$ (b) treats inducers as infringers, so their culpability is similar, even though inducement requires knowledge of the patent

305. Id. at $17-19$

306. Id.

307. Tex. Advanced Optoelectronic Sols., Inc. v. Renesas Elecs. Am., Inc., 139 S. Ct. 2741 (2019).

308. Brief for the United States as Amicus Curiae, Tex. Advanced Optoelectronic Sols., Inc. v. Renesas Elecs. Am., Inc., 139 S. Ct. 2741 (2019) (No. 18-600), 2019 WL 2209264 at *14-15.

309. Id. at III-V (no citations to these cases listed in the Table of Authorities).

310. But see Brief of Intellectual Property Professors as Amici Curiae Supporting Petitioner, Tex. Advanced Optoelectronic Sols., Inc. v. Renesas Elecs. Am., Inc., 139 S. Ct. 2741 (2019) (No. 18-600), 2018 WL 6523955 (applying the RJR Nabisco framework to the issue in the case). In the interest of full disclosure, I was the attorney of record for the brief.

311. See Timothy R. Holbrook, The Supreme Court's Quiet Revolution in Induced Patent Infringement, 91 NOTRE DAME L. REV. 1007, 1010-11 (2016) [hereinafter Holbrook, Quiet Revolution] (discussing history of these provisions).

312. Chisum, supra note 4, at 615.

313. Merial Ltd. v. Cipla Ltd., 681 F.3d 1283, 1302 (Fed. Cir. 2012).

314. Cf. Morrison v. Nat'l Austl. Bank Ltd., 561 U.S. 247, 264 (2010) (“[P]ossible interpretations of statutory language do not override the presumption against extraterritoriality."); see also id. at 266 ("But the presumption against extraterritorial application would be a craven watchdog indeed if it retreated to its kennel whenever some domestic activity is involved in the case."). 
and that the induced acts are infringing. ${ }^{315}$ If the focus is the resulting induced infringement within the United States, the location of the acts of inducement would not matter.

The Supreme Court's examples of a focus analysis are not terribly apt. Morrison's focus analysis is more appropriate in answering the question of whether domestic acts of inducing overseas infringement would be covered, and clearly there would be no induced infringement in that context. Similarly, in WesternGeco, the court turned to the liability generating provision to assess the focus of the damages provision under $\S 284$. The inducement provision similarly requires reference to the direct infringement provision, which does contain the limits. But, if we look at WesternGeco, it did allow foreign damages that flow from such domestic acts of supplying the relevant components. From that perspective, one could view the focus as the domestic acts of infringement and not the acts of inducement.

The case law has made clear, though, that both the act of infringement and the act of inducing that infringement (with requisite knowledge of the patent infringement) are all essential. ${ }^{316}$ The knowledge requirement renders the inducer a bad actor, justifying the imposition of liability. ${ }^{317}$ This approach to acts of inducement outside of the United States yielding domestic infringement is akin to the Transocean scenario, though there necessarily would be domestic activity in the inducement context. The analysis of Transocean would suggest the focus is both the direct infringement and the acts of inducement, and both would need to be within the United States.

Finally, WesternGeco's analysis of damages may have considerable impact on the development of patent law. As discussed above, a number of district courts have summarily determined that WesternGeco overruled the Federal Circuit's bright-line proscription of extraterritorial damages. ${ }^{318}$ The analyses in those cases, however, were divorced from the facts of the case, a necessary component to a focus analysis under step two of the RJR Nabisco framework. The focus analysis of damages for $\S 271$ (a) necessarily requires an analysis of the facts as it relates to that provision, and $\S 271(\mathrm{a})$ is strictly territorial. In contrast, the purpose of $\S 271$ (f) was to afford patent owners some extraterritorial protection.

Those courts also ignore that $\S 271(\mathrm{a})$ is considerably different in terms of its focus. As I have argued, the focus is on acts of domestic infringement, but, in contrast to $\S 271(\mathrm{f})$, nothing contemplates those acts flowing into foreign countries. ${ }^{319}$ Section 271(f) is directed to foreign markets, where $\S 271$ (a) is strictly related to acts within the United States. One can easily see how the focus of $\S 271$ (a) is on domestic acts and markets, including from the perspective of available damages. Otherwise, the Supreme Court's step of looking to $\S 271$ (f) to inform the focus analysis of $\S 284$

315. Global-Tech Appliances, Inc. v. SEB S.A., 563 U.S. 754, 766 (2011); see also Commil USA, LLC v. Cisco Sys., Inc., 575 U.S. 632 (2015) (reaffirming Global-Tech holding).

316. Global-Tech, 563 U.S. at 764-66.

317. Holbrook, Quiet Revolution, supra note 311, at 1015 ("With the knowledge requirement, parties are liable only if they are, in some sense, a bad actor.").

318. See supra notes 274-279 and accompanying text.

319. Holbrook, Boundaries, supra note 96, at 1782. 
would have been superfluous; every form of infringement necessarily entails an award of damages for foreign acts.

Professor Tom Cotter, however, takes a divergent view, arguing that the analysis of WesternGeco does support allowing damages for foreign acts flowing from domestic infringement under $\S 271$ (a). Calling my argument "clever," he views it as "strain[ing] against the actual language of WesternGeco, which repeatedly characterizes the conduct regulated by $\S 271(f)(2)$ as " "domestic" in nature, full stop ...."320 In his view, one could swap the language of $\S 271$ (a) into the reasoning of WesternGeco to yield the same result.

Of course, this approach ignores several aspects of Supreme Court precedent. The first is that the focus analysis is not merely an act of statutory interpretation. Instead, it requires an assessment of the statute relative to the facts of a particular case. Thus, one cannot perform the focus analysis in the abstract. Second, the Court does need to engage with a statute that has clear territorial limits, in contrast with $\S 271(\mathrm{f})$, which the Supreme Court noted protects against the exportation of components of the patented invention, in contrast with wholly domestic activity. To the extent Deepsouth remains good law, it strongly suggests the Supreme Court would be resistant to extending the reach of $\S 271$ (a) - even for damages-beyond the territorial United States. Ultimately, Professor Cotter and I disagree on a key pointwhether the award of damages for foreign activity flowing from domestic acts of infringement is equivalent to finding liability for those same foreign acts. ${ }^{321}$ Ultimately, the courts will have to choose which path to follow regarding extraterritorial damages for infringement under $\S 271(\mathrm{a})$.

\section{INTELLECTUAL PROPERTY EXTRATERRITORIALITY REMAINS INCONSISTENT ... BUT IT SHOULDN'T}

The Supreme Court's trans-substantive articulation of a method for assessing the extraterritorial reach of statutes has been one of its recent enterprises. ${ }^{322}$ While the Court's goal appears to create a standard approach to these issues, the impact has been mixed in intellectual property law. The courts have not approached these issues in a uniform fashion, with many failing to revisit their case law in light of the Supreme Court's tetralogy.

320. Thomas F. Cotter, Extraterritorial Damages in Patent Law, 39 CARDOZO ARTs \& ENT. L.J., draft at 28-29 (forthcoming 2021), https://perma.cc/3X6X-G9U4.

321. We do both agree, however, that proximate cause could do more work to limit damages in these contexts, in alignment with Professor Stephen Yelderman. See id. at 39-40; Holbrook, Proximate Cause, supra note 90, at 223; Yelderman, supra note 283, at 10.

322. See, e.g., Prime Int'1 Trading, Ltd. v. BP P.L.C., 937 F.3d 94, 108 (2d Cir. 2019) (Commodity Exchange Act); Sec. \& Exch. Comm'n v. Scoville, 913 F.3d 1204, 1214 (10th Cir. 2019), cert. denied, 205 L. Ed. 2d 268 (Nov. 4, 2019) (Securities Act and Securities Exchange Act); In re Apple Inc. Device Performance Litig., 347 F. Supp. 3d 434, 448 (N.D. Cal. 2018) (Computer Fraud and Abuse Act), on reconsideration in part, 386 F. Supp. 3d 1155 (N.D. Cal. 2019). 


\section{A. AsSessing the OVErall ImPaCt ON Trademark, COPYRIGHT, AND PATENT}

The courts have, at most, made only minor adjustments to doctrine in trademark and copyright law. There certainly have been no sea changes in the case law. Extraterritoriality issues in these areas have been common for many years, so perhaps it is unsurprising that courts are not willing to revisit the law.

Somewhat surprisingly, the courts in the trademark context have given the new framework the most traction of the three regimes. This embrace is all the more surprising given the inconsistencies between Bulova and the RJR Nabisco framework. Nevertheless, the courts seem to have taken some missteps. The Ninth Circuit's "step 1.5" analysis, which it treats as a second step, is technically part of step one's assessment of the presumption in evaluating any statutory limits on extraterritoriality. ${ }^{323}$ Step one's assessment of whether the presumption has been rebutted is an act of statutory interpretation, making the Ninth Circuit's approach at odds with the approach to step one in other areas of the law. Its "step 1.5" analysis seems akin to the focus analysis under RJR Nabisco's second step. ${ }^{324}$ Instead of discussing structural limits in the statute, the court fell back on its pre-RJR Nabisco methodology that focuses extensively on the facts of the case, making it far more like a focus analysis. It is difficult to imagine how there may be daylight between the two.

The D.C. Circuit's decision in IMAPizza exemplifies the confusion about the presumption's application in trademark and copyright. ${ }^{325}$ In addressing the copyright issue, the court applied its earlier decision in Spanski, which interpreted step two's "focus" analysis, ${ }^{326}$ but did so by jumping straight to step two without reference to the entire two-step methodology. ${ }^{327}$ Within the same opinion, though, the court acknowledged RJR Nabisco's two-step methodology in addressing the trademark claim in the case. But, in this section, the court analyzed step one by applying Bulova. ${ }^{328}$ The court concluded that step one was not satisfied, but it never articulated a "focus" analysis at step two, even though that is what it did for the copyright portion. The opinion itself is internally inconsistent, which is rather perplexing.

In contrast to trademark, where the courts have afforded extraterritorial reach, the courts have adhered strictly to the idea that foreign acts cannot infringe a U.S. copyright such that the presumption will never be rebutted at step one. But the courts have also been quite generous in assessing the focus of the Copyright Act, affording considerable extraterritorial reach through that avenue. The copyright decisions thus show the flexibility of the two-step methodology in creating space for U.S. copyright law - and other laws - to reach extraterritorial activity through the focus analysis.

323. RJR Nabisco, Inc. v. Eur. Cmty., 136 S. Ct. 2090, 2101 (2016) ("The scope of an extraterritorial statute thus turns on the limits Congress has (or has not) imposed on the statute's foreign application, and not on the statute's 'focus."').

324. See supra note 216 and accompanying text.

325. IMAPizza, LLC v. At Pizza Ltd., 965 F.3d 871 (D.C. Cir. 2020).

326. Spanski Enters., Inc. v. Telewizja Polska, S.A., 883 F.3d 904 (D.C. Cir. 2018).

327. IMAPizza, 965 F.3d at 876-79.

328. Id. at $879-81$. 
Relatedly, the survival of the predicate act doctrine means that U.S. copyright holders will be able to avail themselves of foreign acts for purposes of damages, in a manner very similar to patent damages as articulated in WesternGeco.

Finally, patent law's engagement with the presumption has left much to be desired with respect to its adherence to the RJR Nabisco approach, even with WesternGeco dealing directly with patent damages. There is an opportunity for the Federal Circuit to bring its methodology squarely within this framework, which likely will effect some change in its doctrine, if those cases arise. The most dramatic actual and potential impact is in patent law, where much of the Federal Circuit's law arguably is inconsistent with the Supreme Court's approach. That conclusion, though, is perhaps not surprising if one considers the nature of patent law. Because many inventions have clear territorial loci, patent law does tend to be far more territorial in nature. The creative attempts to leverage U.S. patent law into foreign markets has considerable impact.

\section{B. Potential Benefits if Courts Align with the RJR Nabisco FRAMEWORK}

The Supreme Court's endeavor to create a trans-substantive approach to extraterritoriality has not been terribly effective in intellectual property. To the extent that stare decisis, perhaps silently, is generating the reticence of some courts to embrace the Supreme Court's move, there does not seem to be a sufficient basis to retain these earlier methodologies. ${ }^{329}$ Such a failure is disappointing for a key reason: The analyses can be used to inform all areas of the law by comparing the relevant statutes and facts of these cases. Indeed, the reason the Court declined to perform a step one analysis in WesternGeco was fear of having precedential impact beyond patent law.

What the Court saw as a negative can also be a positive, creating cross-fertilization across legal fields to inform the extraterritoriality analysis. If courts in intellectual property cases and elsewhere followed the framework diligently, it should create guidance to all areas of the law as to what statutes are deemed extraterritorial at step one and what fact patterns are deemed within the focus of a statute at step two. Neither of these analyses necessarily depends on the type of law at stake. As the Supreme Court noted in Morrison, "[r]ather than guess anew in each case, we apply the presumption in all cases, preserving a stable background against which Congress can legislate with predictable effects." ${ }^{330}$ Trans-substantive application of the presumption not only helps Congress with its legislation, but it also helps inform the analysis within the courts.

This aspect of the Supreme Court's extraterritoriality agenda resonates with its efforts in patent law: reducing the silos of particular areas of law. In the patent context, commentators have referred to this dynamic as patent exceptionalism, where the courts only rely on patent cases for issues that also arise outside of the patent

329. See Dodge, supra note 1, at 1644-53.

330. Morrison v. Nat'l Austl. Bank Ltd., 561 U.S. 247, 261 (2010). 
context. $^{331}$ In numerous cases, the Supreme Court rejected patent-specific rules in these contexts, bringing patent law back into the fold of other areas of law. ${ }^{332}$ Examples include the standards for permanent injunctions ${ }^{333}$ and for jurisdiction under the Declaratory Judgment Act. ${ }^{334}$ The Court's more recent cases have applied an administrative law lens to the patent system. ${ }^{335}$

Concerns about patent exceptionalism are driven in part by the Federal Circuit. Having a single appellate court deciding all cases arising under the patent laws could create myopia in that court. ${ }^{336}$ But legal exceptionalism need not necessarily be created structurally. Instead, in an effort to treat like cases alike, courts likely turn to other cases within the same area. The review of the extraterritoriality cases in the three areas of federal intellectual property law confirm that dynamic. The courts draw on earlier trademark, copyright, or patent cases in assessing the extraterritoriality reach of the relevant statutes. They do not draw on other areas of the law, within or without intellectual property, to inform their analyses. Such cross-fertilization could be helpful in the intellectual property fields, especially where the fact patterns can have similarities. This could be true even for the fact-intensive focus analysis. Those factual analyses can be useful irrespective of any particular type of law through the common law process. For example, a thorough focus analysis in lieu of the predicate act doctrine could be helpful in assessing similar fact patterns in patent and trademark cases.

\section{As in Trademark, Is There a Role for Comity in Patent AND COPYRIGHT?}

By importing much of its prior case law on extraterritoriality, the courts in trademark law have also preserved a key element of the analysis: comity. ${ }^{337}$ The use of comity has its roots in Bulova, so there is Supreme Court precedent for that consideration. The Supreme Court itself has not fully reconciled the RJR Nabisco framework with potential conflicts with foreign law. While Morrison seemed to eschew comity, Kiobel and RJR Nabisco both seemed to engage with the issue, even

331. See, e.g., Timothy R. Holbrook, Is the Supreme Court Concerned with Patent Law, the Federal Circuit, or Both: A Response To Judge Timothy B. Dyk, 16 ChI.-Kent J. InTELl. Prop. 313, 316 (2017) [hereinafter Holbrook, Response]; Christopher J. Walker, Chevron Deference and Patent Exceptionalism, 65 DUKE L.J. ONLINE 149 (2016); Robin Feldman, Ending Patent Exceptionalism and Structuring the Rule of Reason: The Supreme Court Opens the Door for Both, 15 MinN. J. L. SCI. \& TECH. 61 (2014).

332. Timothy B. Dyk, Thoughts on the Relationship Between the Supreme Court and the Federal Circuit, 16 CHI.-KENT J. INTELL. PROP. 67, 76 (2016) (noting cases in which the Supreme Court reconciled Federal Circuit jurisprudence "with jurisprudence in other areas").

333. eBay Inc. v. MercExchange, L.L.C., 547 U.S. 388, 391 (2006)

334. MedImmune, Inc. v. Genentech, Inc., 549 U.S. 118, 126 (2007).

335. See Thryv, Inc. v. Click-To-Call Techs., LP, 140 S. Ct. 1367 (2020); SAS Inst., Inc. v. Iancu, 138 S. Ct. 1348 (2018); Cuozzo Speed Techs., LLC v. Lee, 136 S. Ct. 2131 (2016). See generally Timothy R. Holbrook, The Federal Circuit's Acquiescence(?), 66 AM. U. L. REV. 1061, 1081-88 (2017).

336. See Holbrook, Response, supra note 331, at 316.

337. To be certain, comity comes in a variety of forms. See generally William S. Dodge, International Comity in American Law, 115 COLUM. L. REV. 2071 (2015). 
if not formally. ${ }^{338}$ While trademark law has long factored potential conflicts with foreign law into its analysis, neither patent law nor copyright law has done so. The Court has considered such issues in other legal areas. ${ }^{339}$

The addition of comity factors should not be precluded by the Supreme Court's new extraterritoriality. ${ }^{340}$ Given the capacious approach the courts have taken regarding the focus analysis, consideration of such comity factors in both patent and copyright could be important. Professor Dodge has noted that reliance on these factors is important in two circumstances: "(1) to provide limits when the presumption has been rebutted at RJR Nabisco step one; and (2) to supplement the test that has been developed by applying the presumption at RJR Nabisco step two." ${ }^{341}$ In patent law, this first circumstance could become important in interpreting the various provisions that explicitly contemplate extraterritorial conduct, specifically $\S 271(\mathrm{f})$ and $(\mathrm{g})$. Additionally, the Supreme Court's greenlight of extraterritorial damages in WesternGeco, through its focus analysis, raises the second circumstance. As Justice Gorsuch suggested in his dissent, affording damages for foreign acts that flow from a domestic act of infringement can have serious consequences within the foreign jurisdiction. ${ }^{342}$

Consideration of comity in all three areas of intellectual property would appear to be a wise course. The courts are increasingly willing to extend U.S. intellectual property rights into foreign markets. The only way to mitigate the potentially deleterious consequences of such extensions is to consider explicitly and formally the potential conflicts of law such acts could create.

338. The Supreme Court appeared poised to address issues of comity in two cases in its 2020 term, Federal Republic of Germany v. Philipp and Republic of Hungary v. Simon. See Brief for Petitioner at i, Federal Republic of Germany v. Philipp, 141 S. Ct. 703 (2021) (No. 19-351) (second question presented asking whether the doctrine of international comity is unavailable); Brief for Petitioner at I, Republic of Hungary v. Simon, 141 S. Ct. 691 (2021) (No. 18-1447) (presenting question of whether district court could abstain from exercising jurisdiction due to comity). The Court ultimately decided the Philipp case on the ground that Germany's appropriation of property may not violate international law which incorporates the domestic takings rule, i.e., "rights in property taken in violation of international law," Fed. Republic of Germany v. Philipp, 141 S. Ct. 703, 715 (2021), and remanded the Simon case in light of that holding, Republic of Hungary v. Simon, 141 S. Ct. 691 (2021) (per curiam). The Court expressly declined to decide the comity question, $141 \mathrm{~S}$. Ct. at 715 , although it did gesture to the presumption against extraterritoriality and the concerns of international friction that animates the presumption in part, id. at 714. See generally William S. Dodge, The Meaning of the Supreme Court's Ruling in Germany v. Philipp, JUST SEC. (Feb. 8, 2021), https://perma.cc/Z6EH-ZZTJ.

339. See, e.g., In re Picard, Tr. for the Liquidation of Bernard L. Madoff Inv. Sec. LLC, 917 F.3d 85, 105 (2d Cir. 2019) (performing comity analysis in a bankruptcy context).

340. See Dodge, supra note 1, at 1623 ("Courts retain authority to impose additional comity limitations on federal statutes ....”).

341. See id. at 1624 .

342. WesternGeco LLC v. ION Geophysical Corp., 138 S. Ct. 2129, 2143 (2018) (Gorsuch, J., dissenting) ("If our courts award compensation to U.S. patent owners for foreign uses where our patents don't run, what happens when foreign courts return the favor? ... A foreign court might reasonably hold the U.S. company liable for infringing the foreign patent in the foreign country. But if it followed WesternGeco's theory, the court might then award monopoly rent damages reflecting a right to control the market for the chip in this country - even though the foreign patent lacks any legal force here. It is doubtful Congress would accept that kind of foreign 'control over our markets.' And principles of comity counsel against an interpretation of our patent laws that would interfere so dramatically with the rights of other nations to regulate their own economies." (quoting Deepsouth, 406 U.S. at 531)). 
2021] Is There A New EXtraterritoriality In Intellectual Property？ 509

\section{CONCLUSION}

If the Supreme Court hoped to bring a harmonized approach to extraterritoriality across all areas of the law, so far its efforts have failed, at least in the intellectual property context. Such failure is a shame. If the courts embraced the RJR Nabsico framework, the courts could use the analysis in these similar areas of law to inform both steps of the framework. Indeed, the Supreme Court has often looked to copyright and patent law to inform the other, given their historic kinship and similar origins in the Constitution. While trademark law may seem to be a more distant cousin in this area, its long history of considering comity in its analysis would be useful in patent and copyright as well. Time will tell whether these areas of intellectual property will converge in their approaches to extraterritoriality. The law would benefit if they do. 